Article

\title{
Synthesis and Cytotoxicity Evaluation of Naphthalimide Derived $N$-Mustards
}

\author{
Qinghua Lou ${ }^{\dagger}$, Liyan Ji ${ }^{\dagger}$, Wenhe Zhong, Shasha Li, Siwang Yu *, Zhongjun Li and \\ Xiangbao Meng *
}

State Key Laboratory of Natural and Biomimetic Drugs, Department of Chemical Biology, School of Pharmaceutical Sciences, Peking University, Beijing 100191, China;

E-Mails: louqh@bjmu.edu.cn (Q.L.); jiliyan@bjmu.edu.cn (L.J.); vicentzhongwh@126.com (W.Z.); shashali@umich.edu (S.L.); zjli@bjmu.edu.cn (Z.L.)

$\dagger$ These authors contributed equally to this work.

* Authors to whom correspondence should be addressed; E-Mails: swang_yu@bjmu.edu.cn (S.Y.); xbmeng@bjmu.edu.cn (X.M.); Tel.: +86-10-8280-1714 (S.Y.\& X.M.);

Fax: +86-10-8280-5496 (S.Y. \& X.M.).

Received: 21 May 2014; in revised form: 10 June 2014 / Accepted: 17 June 2014 /

Published: 25 June 2014

\begin{abstract}
A series of $N$-mustards, which was conjugated to mono- or bis-naphthalimides with a flexible amine link, were synthesized and evaluated for cytotoxicity against five cancer cell lines (HCT-116, PC-3, U87 MG, Hep G2 and SK-OV-3). Several compounds displayed better activities than the control compound amonafide. Further evaluations by fluorescence spectroscopy studies and DNA-interstrand cross-linking assays revealed that the derivatives showed both alkylating and intercalating properties. Among the derivatives, the bis-naphthalimide $N$-mustard derivative 11b was found to exhibit the highest cytotoxic activity and DNA cross-linking ability. Both $\mathbf{1 1 b}$ and $\mathbf{7 b}$ induce HCT-116 cell apoptosis by S phase arrest.
\end{abstract}

Keywords: cytotoxicity; DNA alkylating agent; DNA intercalator; synthesis; $N$-mustard; naphthalimide 


\section{Introduction}

As the earliest agents used for chemotherapy, DNA alkylating nitrogen mustards have been widely utilized in oncology treatment, and many such agents are still in clinical use (Figure 1) [1-5]. However, progress in developing new $N$-mustard agents is limited due to its drawbacks [6]. Its necessarily high chemical reactivity leads to serious adverse effects $[3,7,8]$ by randomly alkylating other cellular nucleophiles. They lack specific affinity to tumor cells and induce bone marrow toxicity $[6,9]$. To overcome those drawbacks, one of the strategies has been to synthesize bifunctional compounds by linking $N$-mustards with DNA-affine molecules, such as DNA-intercalators (e.g., acridines [6,9,10], cyclopentanthraquinone [11]) or DNA minor groove binders (e.g., distamycin A and related analogues [12-14]). Previous research has demonstrated that linking with an appropriate carrier can modify the specificity of DNA alkylation and thus improve the therapeutic efficacy of $N$-mustard agents. This strategy has been widely applied in the search for new drugs $[9,15,16]$.

Figure 1. Chemical structures of $N$-mustard antineoplastic drugs and derivatives.

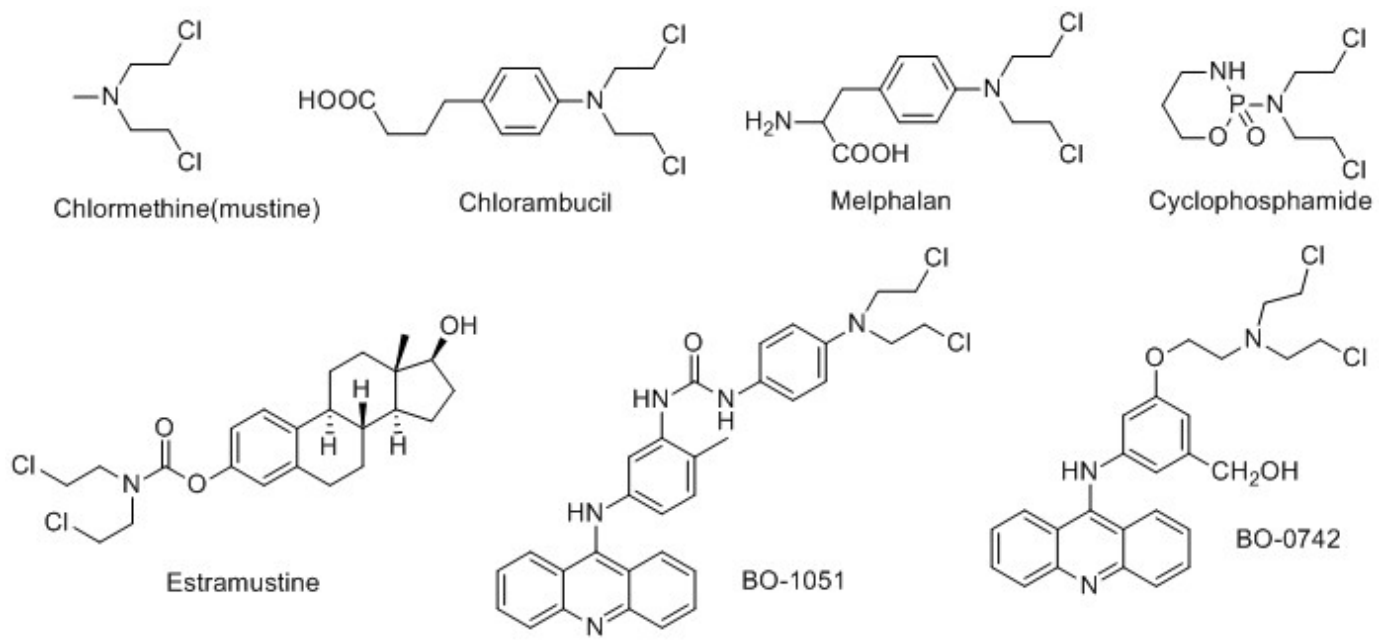

Naphthalimide, a well-defined DNA-intercalator, has been extensively investigated as an antitumor agent [17]. Several naphthalimide derivatives such as mitonafide, amonafide, ethonafide, elinafide, and bisnafide (Figure 2) are currently undergoing clinical trials, [17]. Elinafide and bisnafide, which are bisintercalators prepared by linking two naphthalimide groups with a polyamine linker, showed much higher cytotoxicity than the mono-intercalators mitonafide and amonafide [18,19]. However, only limited research have been done in the area of linking $N$-mustard with DNA-binding naphthalimide, and they showed enhanced cytotoxicities [20-23].

Herein, we designed and synthesized $N$-mustard derivatives of naphthalimides by linking the $N$-mustard moiety with naphthalimides. The conjugates acted as both alkylating agents and intercalators. Encouraged by the generally stronger cytotoxicities and high binding capacities of the bis-intercalators, we decided to synthesize both mono and bis-naphthalimide [18] conjugates to compare their cytotoxic activities. 
Figure 2. Structures of naphthalimides and $\mathrm{N}$-mustard analogs.

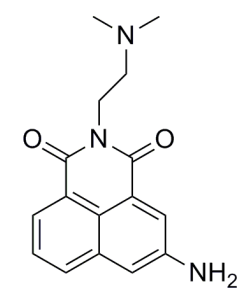

amonafide

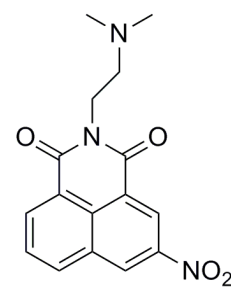

mitonafide

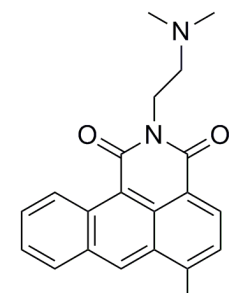

ethonafide OEt

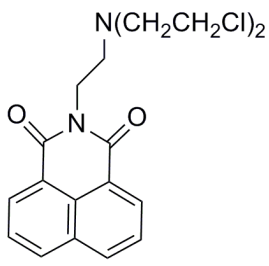

Naphthalmustine
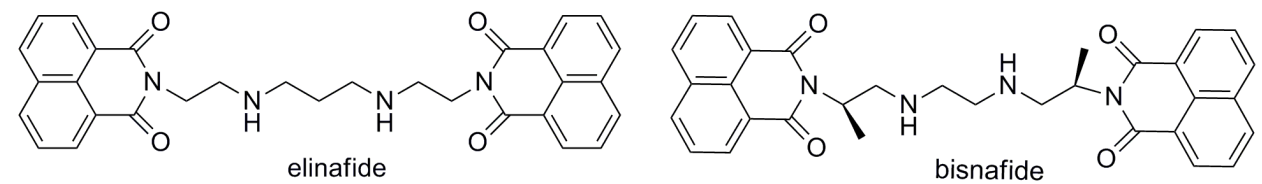

\section{Results and Discussion}

\subsection{Chemistry}

To attach the $N$-mustard moiety to the naphathalimide core, we synthesized compound $\mathbf{2}$ from naphthalic anhydride [24,25]. Compound 2 was refluxed with an aminoalcohol in $\mathrm{CH}_{3} \mathrm{CN}$ to yield the key precursor compound $\mathbf{3}$, which was converted to compound $\mathbf{4}$ by refluxing in $\mathrm{HCHO}$ and $\mathrm{HCOOH}$. The chlorination of alcohol 4 in the presence of $\mathrm{SOCl}_{2}$ to produce 5 was successful [26]. The $N$-mustard precursor $\mathbf{6}$ was synthesized by condensing compound $\mathbf{5}$ with diethanolamine in the presence of $\mathrm{K}_{2} \mathrm{CO}_{3} / \mathrm{KI}$ [27]. The final target compound 7 was obtained from 6 by reacting with $\mathrm{SOCl}_{2}(\mathrm{Scheme} 1)$.

Scheme 1. Synthesis of compounds 7a-b.

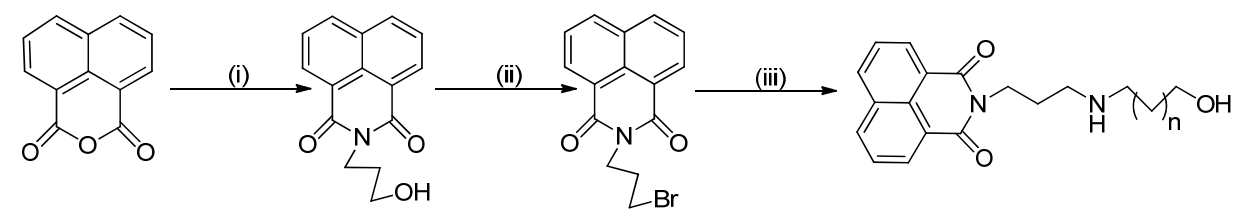

$12 \begin{aligned} & 3 \mathbf{a} n=0 \\ & \mathbf{3 b} n=1\end{aligned}$
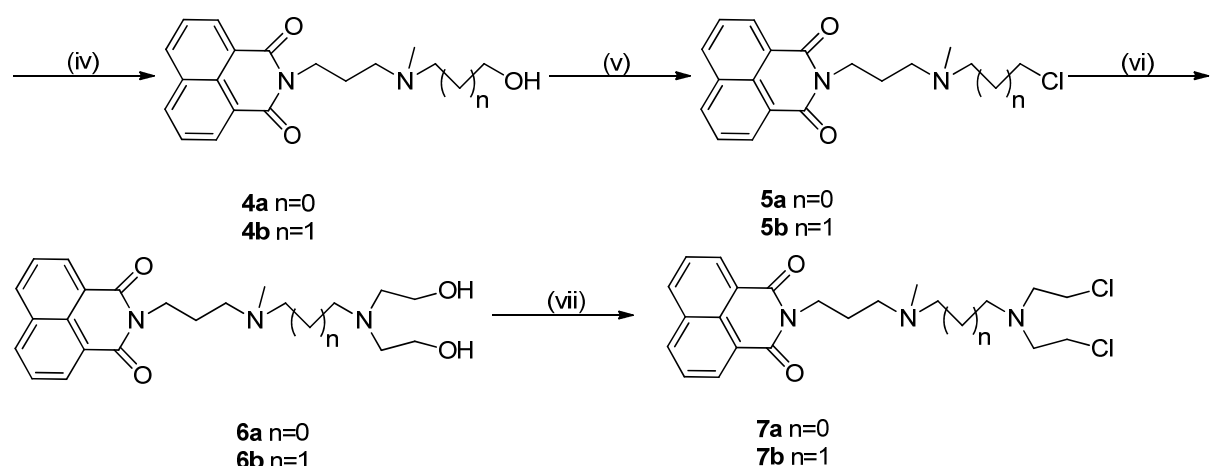

$6 \mathbf{a} n=0$
$6 \mathbf{b} n=1$

$7 \mathbf{b} n=1$

Reagents and conditions: (i) 3-amino-1-propanol, EtOH, reflux; (ii) $\mathrm{PPh}_{3} / \mathrm{NBS}, \mathrm{CH}_{2} \mathrm{Cl}_{2}$, rt; (iii) aminoalcohol, $\mathrm{K}_{2} \mathrm{CO}_{3}, \mathrm{CH}_{3} \mathrm{CN}, 70{ }^{\circ} \mathrm{C}$; (iv) $\mathrm{HCHO} / \mathrm{HCOOH}$, reflux; (v) $\mathrm{SOCl}_{2}, \mathrm{CHCl}_{3}$, rt; (vi) diethanolamine, $\mathrm{K}_{2} \mathrm{CO}_{3} / \mathrm{KI}, \mathrm{CH}_{3} \mathrm{CN}$, reflux; (vii) $\mathrm{SOCl}_{2}$, reflux.

The synthesis of bis-naphthalimide derivatives is illustrated in Scheme 2. Starting from compound 2, the target compounds 11a,b were obtained following the procedures described below. 
Scheme 2. Synthesis of bis-naphthalimide derivatives.

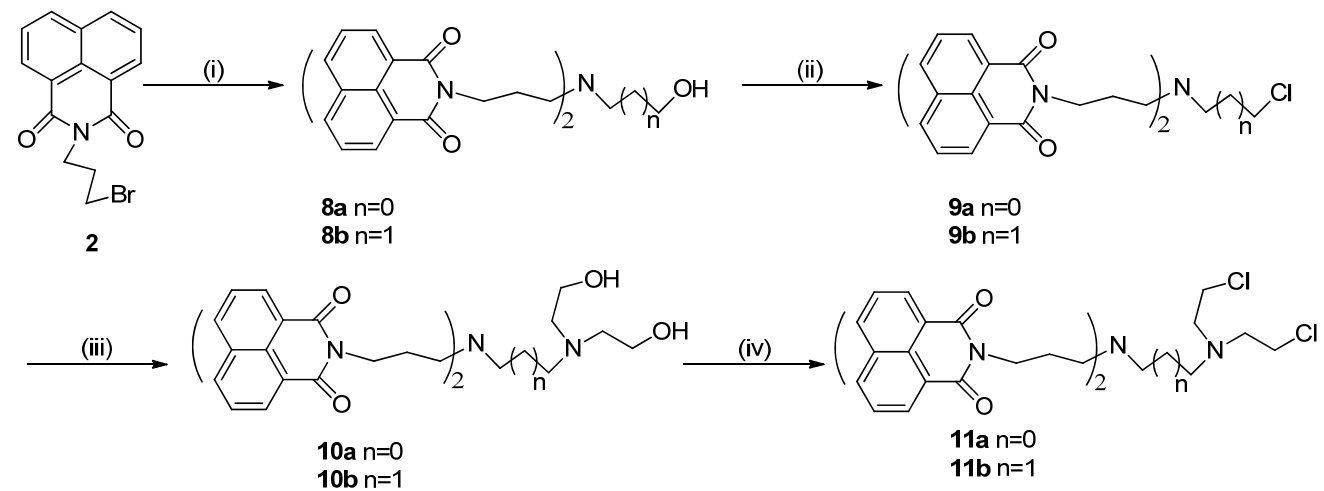

Reagents and conditions: (i) aminoalcohol, $\mathrm{K}_{2} \mathrm{CO}_{3}, \mathrm{CH}_{3} \mathrm{CN}, 80{ }^{\circ} \mathrm{C}$; (ii) $\mathrm{SOCl}_{2}, \mathrm{CH}_{2} \mathrm{Cl}_{2}$, rt; (iii) diethanolamine, $\mathrm{K}_{2} \mathrm{CO}_{3} / \mathrm{KI}, \mathrm{CH}_{3} \mathrm{CN}$, reflux; (iv) $\mathrm{SOCl}_{2}$, reflux.

\subsection{Biological Assay}

\subsubsection{Cytotoxic Activity}

The $N$-mustard naphthalimide derivatives $7 \mathbf{a}-\mathbf{b}, \mathbf{1 1 a}-\mathbf{b}$ and the precursors $6 \mathbf{a}-\mathbf{b}, \mathbf{1 0 a}-\mathbf{b}$ in their dihydrochloride forms were screened for their cytotoxic activities against five cancer cell lines, which were HCT-116 (colorectal carcinoma), PC-3 (prostate carcinoma), U87 MG (brain tumor), Hep G2 (liver cancer), and SK-OV-3 (ovarian cancer), with an in vitro cell growth assay using amonafide as positive control. The results were listed in Table 1. The activity of compound 11b was the highest among all the compounds and was increased by several fold (1.4-11) compared to amonafide, while compound $\mathbf{7 b}$ showed a similar activity with amonafide. $N$-mustards $\mathbf{7 b}$ and $\mathbf{1 1 b}$ displayed more activity than their precursors $\mathbf{6 b}, \mathbf{1 0 b}$. Furthermore, compared with compounds $7 \mathbf{b}$ and $\mathbf{1 1 b}, \mathbf{7 a}$ and $11 \mathbf{a}$ unexpectedly showed much lower activities $(>10 \mu \mathrm{M})$. Because quaternary ammonium salts of $7 \mathbf{a}$ and 11a were used in this cytotoxicity assay, the six-membered rings in 7a and 11a, which make them less flexible, may be the reason for the lower activities.

Table 1. $\mathrm{IC}_{50}$ values of naphthalimide derivatives against five cancer cell lines ${ }^{\mathrm{a}}$.

\begin{tabular}{cccccc}
\hline \multirow{2}{*}{ Compound $^{\mathbf{b}}{ }^{\mathbf{n}}$} & \multicolumn{5}{c}{$\mathbf{I C}_{\mathbf{5 0}}(\boldsymbol{\mu M})$} \\
\cline { 2 - 6 } & $\mathbf{H C T - 1 1 6}$ & $\mathbf{P C - 3}$ & $\mathbf{U 8 7 M G}$ & Hep G2 & SK-OV-3 \\
\hline $\mathbf{6 a}$ & $73.77 \pm 2.54$ & $225.80 \pm 6.41$ & $40.80 \pm 3.14$ & $42.81 \pm 26.39$ & $63.35 \pm 5.42$ \\
$\mathbf{6 b}$ & $6.96 \pm 1.64$ & $69.97 \pm 10.14$ & $10.24 \pm 0.19$ & $9.39 \pm 4.37$ & $12.76 \pm 1.40$ \\
$\mathbf{7 a}$ & $33.29 \pm 3.13$ & $73.10 \pm 14.61$ & $10.77 \pm 0.07$ & $15.38 \pm 2.88$ & $35.31 \pm 5.69$ \\
$\mathbf{7 b}$ & $2.42 \pm 0.12$ & $3.02 \pm 0.34$ & $1.95 \pm 0.07$ & $1.40 \pm 0.07$ & $5.59 \pm 0.70$ \\
$\mathbf{1 0 a}$ & $1.30 \pm 0.09$ & $2.98 \pm 0.08$ & $1.77 \pm 0.14$ & $1.25 \pm 0.16$ & $2.33 \pm 0.28$ \\
$\mathbf{1 0 b}$ & $2.80 \pm 0.36$ & $3.33 \pm 0.17$ & $2.04 \pm 0.13$ & $0.82 \pm 0.06$ & $2.43 \pm 0.13$ \\
$\mathbf{1 1 a}$ & $31.54 \pm 18.66$ & $96.35 \pm 64.69$ & $24.88 \pm 3.17$ & $31.76 \pm 18.21$ & $15.40 \pm 6.22$ \\
$\mathbf{1 1 b}$ & $1.01 \pm 0.06$ & $0.35 \pm 0.03$ & $0.39 \pm 0.03$ & $0.89 \pm 0.15$ & $0.61 \pm 0.04$ \\
Amonafide & $4.81 \pm 0.54$ & $3.89 \pm 0.28$ & $2.60 \pm 0.32$ & $1.23 \pm 0.07$ & $5.10 \pm 0.76$ \\
\hline
\end{tabular}

${ }^{\text {a }}$ Cell growth inhibition was measured by the MTT assay, and values were expressed as mean $\mathrm{IC}_{50}$ of the triplicate experiment; ${ }^{\mathrm{b}}$ All these compounds $(\mathbf{6}, \mathbf{7}, \mathbf{1 0}, \mathbf{1 1})$ are in its di-hydrochloride forms. 
We also screened all the synthetic intermediates in its mono-hydrochloride form against the same five cancer cell lines (Table 2). It was unexpected to find that compounds $\mathbf{8 a}$ and $\mathbf{8 b}$ which acted only as DNA-intercalators, exhibited close activities to $\mathbf{1 1 b}$. These results indicated that $N$-mustards can increase the cytotoxic activity of the naphathalimide derivatives, but not efficiently.

Table 2. $\mathrm{IC}_{50}$ values of synthetic intermediates over five cancer cell lines ${ }^{\mathrm{a}}$.

\begin{tabular}{cccccc}
\hline \multirow{2}{*}{ Compound $^{\mathbf{b}}{ }^{\mathbf{n}}$} & \multicolumn{5}{c}{$\mathbf{I C}_{\mathbf{5}}(\boldsymbol{\mu} \mathbf{M})$} \\
\cline { 2 - 6 } & $\mathbf{H C T}-\mathbf{1 1 6}$ & $\mathbf{P C - 3}$ & $\mathbf{U 8 7 M G}$ & Hep G2 & SK-OV-3 \\
\hline $\mathbf{3 a}$ & $13.45 \pm 0.88$ & $45.82 \pm 3.13$ & $15.39 \pm 1.39$ & $22.60 \pm 8.29$ & $24.18 \pm 4.64$ \\
$\mathbf{3 b}$ & $12.52 \pm 1.47$ & $49.17 \pm 6.69$ & $14.25 \pm 1.19$ & $12.17 \pm 0.65$ & $17.48 \pm 1.68$ \\
$\mathbf{4 a}$ & $12.00 \pm 0.46$ & $25.54 \pm 2.24$ & $14.08 \pm 0.86$ & $9.43 \pm 2.39$ & $15.07 \pm 2.17$ \\
$\mathbf{4 b}$ & $23.72 \pm 2.53$ & $67.16 \pm 8.79$ & $27.50 \pm 5.02$ & $18.80 \pm 1.91$ & $21.05 \pm 3.09$ \\
$\mathbf{5 a}$ & $8.44 \pm 0.68$ & $7.40 \pm 0.64$ & $3.33 \pm 0.37$ & $4.20 \pm 0.20$ & $16.71 \pm 1.47$ \\
$\mathbf{5 b}$ & $81.69 \pm 3.79$ & $64.16 \pm 14.12$ & $36.89 \pm 13.15$ & $31.19 \pm 1.09$ & $102.58 \pm 6.99$ \\
$\mathbf{8 a}$ & $0.78 \pm 0.06$ & $1.83 \pm 0.07$ & $0.77 \pm 0.02$ & $0.71 \pm 0.10$ & $0.89 \pm 0.03$ \\
$\mathbf{8 b}$ & $0.77 \pm 0.05$ & $1.38 \pm 0.18$ & $0.65 \pm 0.02$ & $0.56 \pm 0.02$ & $0.87 \pm 0.03$ \\
$\mathbf{9 b}$ & $2.07 \pm 0.24$ & $14.60 \pm 0.53$ & $2.26 \pm 0.37$ & $1.04 \pm 0.07$ & $5.29 \pm 0.31$ \\
amonafide & $4.81 \pm 0.54$ & $3.89 \pm 0.28$ & $2.60 \pm 0.32$ & $1.23 \pm 0.07$ & $5.10 \pm 0.76$ \\
\hline
\end{tabular}

${ }^{a}$ Cell growth inhibition was measured by the MTT assay, and values were expressed as mean $\mathrm{IC}_{50}$ of the triplicate experiment. ${ }^{\mathrm{b}}$ All these compounds $(\mathbf{3}, \mathbf{4}, \mathbf{5}, \mathbf{8}, \mathbf{9})$ are in its mono-hydrochloride forms.

Figure 3. Fluorescence spectra of (a) $6 \mathrm{~b}(\mathbf{b}) 7 \mathbf{b}(\mathbf{c}) \mathbf{1 0 b}(\mathbf{d}) \mathbf{1 1 b .}$

(a)

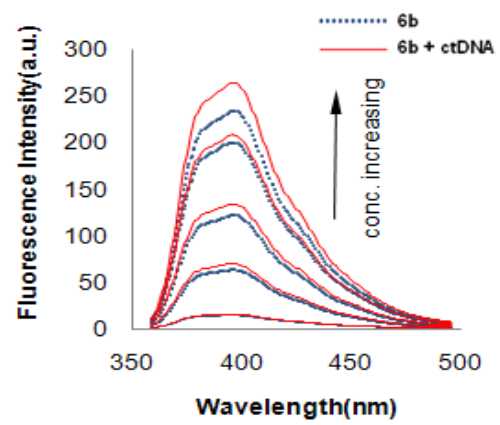

(C)

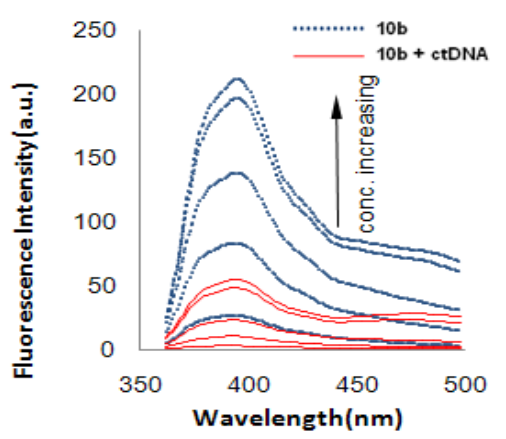

(b)

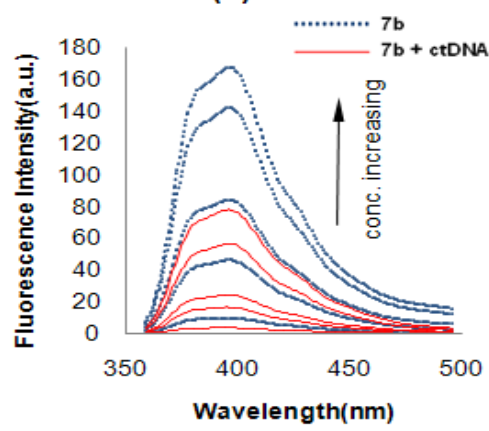

(d)

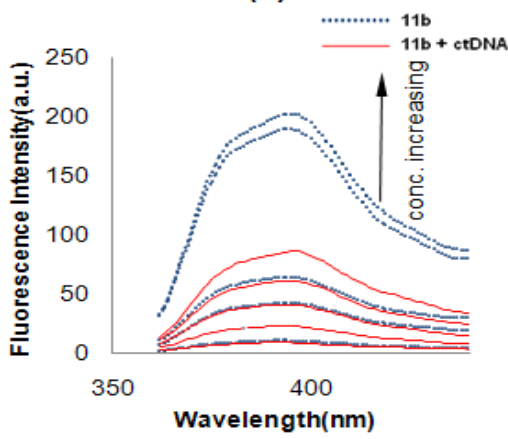

Conditions: Fluorescence spectra of (a) $6 \mathbf{b}$ (b) $7 \mathbf{b}$ (c) 10b (d) 11b (all in their dihydrochloride form) at different concentrations after incubated with ctDNA $(50 \mu \mathrm{M})$. The concentrations of the four compounds were 1, 5, 10, 20 and $25 \mu \mathrm{M}$. The insets showed the relationship between the intensity of fluorescence and the concentration of the four compounds. 


\subsubsection{Fluorescence Studies}

A fluorescence study was employed to evaluate the interaction properties of the synthesized derivatives with DNA. Figure 3 illustrates the changes of fluorescence properties of compounds $\mathbf{6 b}, \mathbf{7 b}$, 10b and 11b before and after being mixed with calf thymus DNA (ctDNA). The solutions of various concentrations of compounds with ctDNA were incubated at $30^{\circ} \mathrm{C}$ for 3 days, then the florescence spectra were recorded. We found that the fluorescence intensity of compound $\mathbf{6 b}$ showed little change with or without ctDNA at all five concentrations, indicating a weak intercalating ability. On the contrary, compound $\mathbf{7 b}$ exhibited an evident decrease of fluorescence intensity when ctDNA was added, which demonstrated the $N$-mustard is essential to increase the binding strength to DNA. Both compounds 10b and 11b showed obvious decreases of fluorescence intensity, but the difference between them is not significant. Those results indicate that: (1) an $\mathrm{N}$-mustard residue is able to stabilize the DNA-compound complex after the intercalating process, and the binding potency is enhanced for $N$-mustard derivatives; (2) bis-naphthalimides 10b, 11b show generally much higher intercalating potential than mono-naphthalimides such as $\mathbf{6 b}, \mathbf{7 b}$, which is in accordance with previous research [19].

Figure 4. Agarose Gel Cross-Link Assay.

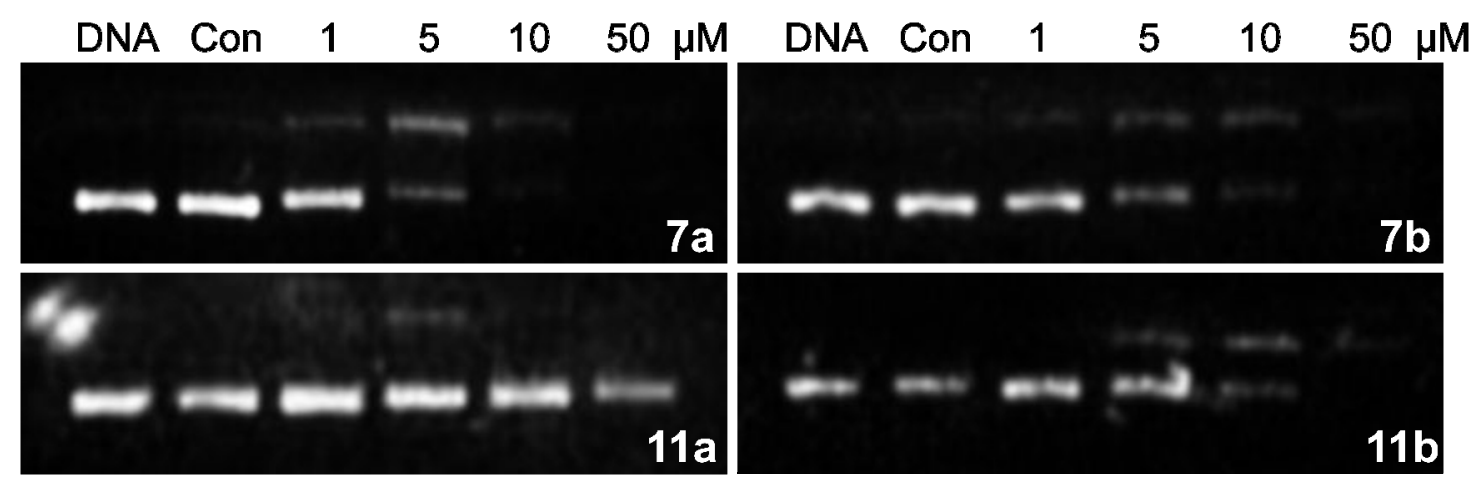

Conditions: compound and $2 \mu \mathrm{L}$ supercoiled plasmid DNA (pUC-19, $0.16 \mu \mathrm{g} / \mu \mathrm{L}$ ) were incubated at $37{ }^{\circ} \mathrm{C}$ for $1 \mathrm{~h}$ in Tris- $\mathrm{HCl}$ buffer $(0.05 \mathrm{M}, \mathrm{pH}=7.4)$. Con: precursor of each specific nitrogen mustard $(\mathbf{6 a} / \mathbf{b}, \mathbf{1 0 a} / \mathbf{b})$. Concentrations of drugs, from left to right: $1,5,10,50 \mu \mathrm{M}$. All the compounds used in the assay are in their dihydrochloride form.

\subsubsection{DNA Interstrand Cross-Linking Assay}

To evaluate the potency of DNA interstrand cross-linking brought by the $N$-mustard moiety [15], compounds 7a, $\mathbf{b}$ and 11a, $\mathbf{b}$ were selected to undergo an agarose gel cross-linking assay, at four concentration levels (Figure 4). Considering that naphthalimide chromophore can intercalate with DNA and so slow down DNA migration on the gel, 6a,b and 10a,b were employed, respectively, as controls for each mustine derivative. Compounds $\mathbf{7 a}, \mathbf{7 b}$ and $\mathbf{1 1} \mathbf{b}$ displayed DNA cross-linking potency at 1,1 and $5 \mu \mathrm{M}$, respectively; while 11a displayed almost no DNA cross-linking ability. The results for $\mathbf{7 b}, \mathbf{1 1 a}$ and 11b were consistent with their cytotoxic data. However, different from the cytotoxicity data, 7a exhibited high DNA cross-linking activity, even at $1 \mu \mathrm{M}$ concentration. The different performance of $\mathbf{7 a}$ in cells and under agarose gel (with Tris-HCl buffer) conditions may result from its insufficient transmembrane access to the nucleus. The controls $\mathbf{1 0 a}$ and $\mathbf{1 0 b}$ displayed no 
DNA cross-linking abilities when compared with the $N$-mustards 11a and 11b, which showed similar activities in the previous tests. This result suggested the possibility that the $N$-mustard moiety did not show significant differences in in vitro tests, but played an efficient role in interacting with DNA.

\subsubsection{Flow Cytometry Assay}

Compounds that target DNA by intercalating or cross-linking often interfere with cellular DNA replication, thus inhibiting cell proliferation by inducing cell cycle arrest. To evaluate the effects of the compounds on cell cycle progression, the cell cycle distribution of HCT-116 cells was examined by flow cytometry after treatment with indicated concentrations of compounds $\mathbf{7 b}, \mathbf{9 b}$ and $\mathbf{1 1 b}$ for $24 \mathrm{~h}$. As shown in Figure 5, compounds $\mathbf{7 b}$ and $\mathbf{1 1 b}$ induced G2/M and S phase cell cycle arrest, suggesting that these compounds could interfere with DNA synthesis. Compound 11b showed a more pronounced arrest in $\mathrm{G} 2 / \mathrm{M}$ phase at $1 \mu \mathrm{M}$ than $\mathbf{7 b}$, which is in agreement with the higher cytotoxicity associated with 11b. However, compound 9b, a homo- $N$-mustard, exhibited marginal effects on the cell cycle distribution, even at $5 \mu \mathrm{M}$, implying the $N$-mustard moiety is essential for inhibition of DNA synthesis.

Figure 5. Effects of compounds on cell cycle distribution of HCT-116 cells.

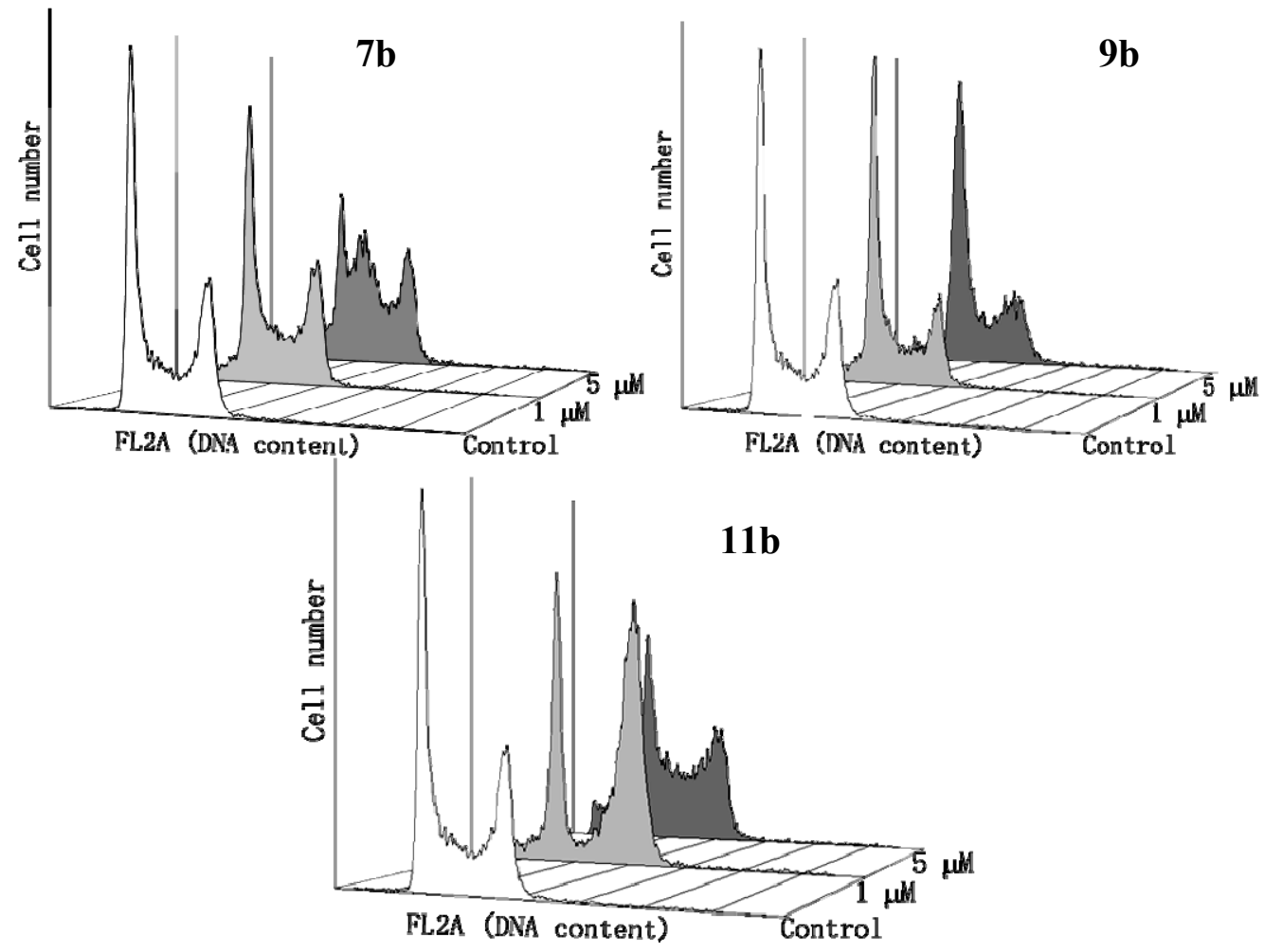

Conditions: Cells were incubated with indicated concentrations of $\mathbf{7 b}, \mathbf{9 b}, \mathbf{1 1 b}$ for $24 \mathrm{~h}$, then cells were stained by PI $(20 \mu \mathrm{g} / \mathrm{mL})$ and tested by flow cytometry.

\subsubsection{Immunoblotting Assay}

Poly(ADP-ribose) polymerase (PARP-1) is specifically cleaved by caspases during the execution phase of apoptosis in response to DNA damage, thus its cleavage has been regarded as a biomarker of apoptosis [28]. Therefore, the cleavage of PARP-1 in HCT-116 cells treated with various compounds was detected by western blotting. As shown in Figure 6, both $\mathbf{7 b}$ and $\mathbf{1 1 b}$ induced significant cleavage 
of the original $116 \mathrm{kDa}$ PARP-1 into $89 \mathrm{kDa}$ and $24 \mathrm{kDa}$ fragments, suggesting that these two compounds induced DNA-damage related apoptosis. In agreement with the results above, the homomustard 9b showed no observable effect on the cleavage of PARP-1. Taken together, the above results suggest that compounds $\mathbf{7 b}$ and $\mathbf{1 1 b}$ induced DNA damage-related cell cycle arrest and apoptosis in HCT-116 cells, but 9b might have a different mechanism of action.

Figure 6. Effect of compounds on PARP-1 cleavage in HCT-116 cell.

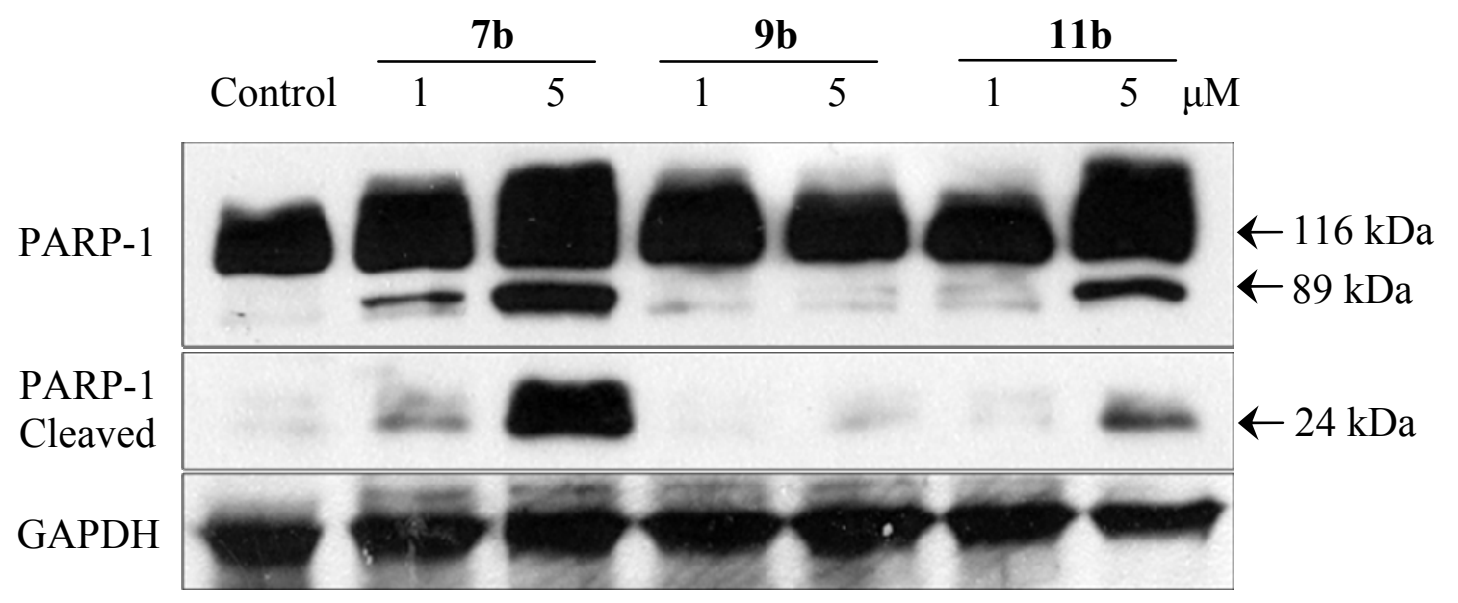

Conditions: HCT-116 cells were treatment for $24 \mathrm{~h}$ in the presence of indicated concentrations of $\mathbf{7 b}, \mathbf{9 b}, \mathbf{1 1} \mathbf{b}$, and then cleavage of PARP1 was detected by immunoblotting. GAPDH, a house-keeping gene product, was used as loading control.

\section{Experimental Section}

\subsection{General Information}

All the solvents were of analytical grade. ${ }^{1} \mathrm{H}-\mathrm{NMR}$ and ${ }^{13} \mathrm{C}-\mathrm{NMR}$ spectra were obtained with JEOL-300 all examples below are $300 \mathrm{MHz}$ but in Supplementary file spectra are labelled as $400 \mathrm{Mhz}$. Explain this confusing situation spectrometers. The chemical shifts were reported in ppm using TMS as internal standard. High resolution mass spectrometry was measured on a Bruker MicrOTOF-Q. Column chromatography was conducted on silica gel (200 300 mesh). Temperature range for $\mathrm{rt}$ is $25 \pm 2{ }^{\circ} \mathrm{C}$.

\subsection{Synthesis}

2-(3-Hydroxypropyl)-1H-benzo[de]isoquinoline-1,3(2H)-dione (1) [24]. A mixture of 1,8-naphthalic anhydride (4 g, $20.8 \mathrm{mmol})$ and 3-amino-1-propanol (1.86 mL, $24.6 \mathrm{mmol})$ in ethanol (40 mL) was heated under reflux for $5 \mathrm{~h}$. The resulting mixture was concentrated by evaporating ethanol under reduced pressure to afford a solid residue, which was purified by column chromatography over silica gel $\left(\mathrm{CH}_{2} \mathrm{Cl}_{2} / \mathrm{MeOH}=1: 1\right)$ to afford compound 1 as an off-white solid $(4.27 \mathrm{~g}, 83 \%)$.

2-(3-Bromopropyl)-1H-benzo[de] isoquinoline-1,3(2H)-dione (2) [25]. To a solution of compound 1 (2 g, $7.84 \mathrm{mmol})$ and NBS $(2.12 \mathrm{~g}, 11.9 \mathrm{mmol})$ in dichloromethane $(20 \mathrm{~mL}$, dry $)$ was added $\mathrm{PPh}_{3}(2.49 \mathrm{~g}$, $8.2 \mathrm{mmol}$ ) in portions in an ice bath. The resulting solution was kept at room temperature overnight, 
and then purified by column chromatography over silica gel (petroleum ether/ $\mathrm{CH}_{2} \mathrm{Cl}_{2}=3: 1$ ) to afford compound 2 (2.25 g, 90\%).

$\mathrm{N}$-[2-(1,3-Dioxo-2,3-dihydro-1H-benz[de]-isoquinolin-2-yl)propyl]-ethanolamine (3a). A mixture of compound 2 ( $1 \mathrm{~g}, 3.15 \mathrm{mmol})$, ethanolamine $(2 \mathrm{~mL}, 33.1 \mathrm{mmol})$ and $\mathrm{K}_{2} \mathrm{CO}_{3}(1.8 \mathrm{~g}, 13.0 \mathrm{mmol})$ in $10 \mathrm{~mL}$ of $\mathrm{CH}_{3} \mathrm{CN}$ was heated at $70{ }^{\circ} \mathrm{C}$ for $30 \mathrm{~h}$. The resulting mixture was filtered to remove the $\mathrm{K}_{2} \mathrm{CO}_{3}$ residue, condensed in vacuo, then dissolved in $\mathrm{H}_{2} \mathrm{O}(80 \mathrm{~mL})$ and extracted with $\mathrm{CH}_{2} \mathrm{Cl}_{2}(100 \mathrm{~mL})$. The extract was dried over $\mathrm{Na}_{2} \mathrm{SO}_{4}$ and purified by column chromatography $\left(\mathrm{CH}_{2} \mathrm{Cl}_{2} / \mathrm{MeOH}=20: 1 \sim 10: 1\right)$ to yield pure 3a $(0.79 \mathrm{~g}, 80 \%)$ as a faint yellow solid. ${ }^{1} \mathrm{H}-\mathrm{NMR}\left(300 \mathrm{MHz}, \mathrm{CDCl}_{3}\right) \delta_{\mathrm{H}}(\mathrm{ppm}): 1.94-2.01(\mathrm{~m}$, 2H), 2.69-2.76 (m, 4H, $\mathrm{NHCH}_{2}$ and $\left.\mathrm{OH}\right), 2.82(\mathrm{t}, 2 \mathrm{H}, J=5.1 \mathrm{~Hz}), 3.66(\mathrm{t}, 2 \mathrm{H}, J=5.1 \mathrm{~Hz}), 4.29$ (t, $2 \mathrm{H}, J=6.9 \mathrm{~Hz}), 7.75(\mathrm{dd}, 2 \mathrm{H}, J=7.5,8.1 \mathrm{~Hz}), 8.21$ (d, 2H, $J=8.4 \mathrm{~Hz}), 8.59$ (d, 2H, $J=7.2 \mathrm{~Hz})$. ${ }^{13} \mathrm{C}-\mathrm{NMR}\left(75 \mathrm{MHz}, \mathrm{CDCl}_{3}\right.$ ): $\delta$ 164.3(2C), 134.0 (2C), 131.3 (4C), 126.9 (2C), 122.5 (2C), 60.6, 50.9, 46.2, 38.1, 28.3.HRMS (ESI): Calcd for $\mathrm{C}_{17} \mathrm{H}_{19} \mathrm{~N}_{2} \mathrm{O}_{3}: 299.1390[\mathrm{M}+\mathrm{H}]^{+}$, Found: $299.1383[\mathrm{M}+\mathrm{H}]^{+}$.

N-[2-(1,3-Dioxo-2,3-dihydro-1H-benz[de]-isoquinolin-2-yl)propyl]-3-amino-1-propanol (3b). Compound 3b was synthesized by a similar procedure as the synthesis of 3a. Compound 2 (1 g, $3.15 \mathrm{mmol})$ and 3-amino-1-propanol (2 mL, $27.1 \mathrm{mmol}$ ) were employed to produce $\mathbf{3 b}$ (yellow oil, $0.89 \mathrm{~g}, 91 \%$ ). ${ }^{1} \mathrm{H}-\mathrm{NMR}$ $\left(300 \mathrm{MHz}, \mathrm{CDCl}_{3}\right) \delta_{\mathrm{H}}(\mathrm{ppm}): 1.73-1.76(\mathrm{~m}, 2 \mathrm{H}), 1.95-2.00(\mathrm{~m}, 2 \mathrm{H}), 2.73(\mathrm{t}, 2 \mathrm{H}, J=6.6 \mathrm{~Hz}), 2.90$ (t, $1 \mathrm{H}, J=5.4 \mathrm{~Hz}, \mathrm{NH}), 3.46-3.47\left(\mathrm{~m}, 3 \mathrm{H}, \mathrm{CH}_{2} \mathrm{~N}, \mathrm{OH}\right), 3.83(\mathrm{t}, 2 \mathrm{H}, J=5.1 \mathrm{~Hz}), 4.24(\mathrm{t}, 2 \mathrm{H}, J=6.3 \mathrm{~Hz})$, $7.71-7.76(\mathrm{~m}, 2 \mathrm{H}), 8.19(\mathrm{~d}, 2 \mathrm{H}, J=7.2 \mathrm{~Hz}), 8.70(\mathrm{~d}, 2 \mathrm{H}, J=6.0 \mathrm{~Hz}) .{ }^{13} \mathrm{C}-\mathrm{NMR}\left(75 \mathrm{MHz}, \mathrm{CDCl}_{3}\right)$ : $\delta 164.2$ (2C), 133.9 (2C), 131.4, 131.2 (3C), 126.8 (2C), 122.3 (2C), 63.7, 49.2, 46.7, 37.9, 30.6, 27.9; HRMS (ESI): Calcd for $\mathrm{C}_{18} \mathrm{H}_{21} \mathrm{~N}_{2} \mathrm{O}_{3}: 313.1547[\mathrm{M}+\mathrm{H}]^{+}$, Found: $313.1555[\mathrm{M}+\mathrm{H}]^{+}$.

$N$-[2-(1,3-Dioxo-2,3-dihydro-1H-benz[de]-isoquinolin-2-yl)propyl]-N-methylethanolamine (4a). To formaldehyde $(37 \%, 1.2 \mathrm{~mL})$ was added formic acid $(5 \mathrm{~mL})$ dropwise in an ice bath, and the resulting solution was added into compound 3a $(711 \mathrm{mg}, 2.39 \mathrm{mmol})$ and stirred for $10 \mathrm{~min}$ in an ice bath, then heated to $105{ }^{\circ} \mathrm{C}$ overnight. Removal of residual formaldehyde and formic acid under reduced pressure gave crude product, which was dissolved in water and treated with $\mathrm{Na}_{2} \mathrm{CO}_{3}$ to $\mathrm{pH}>7$, and extracted with $\mathrm{CH}_{2} \mathrm{Cl}_{2}$. The organic layer was dried with $\mathrm{Na}_{2} \mathrm{SO}_{4}$ and purified by column chromatography $\left(\mathrm{CHCl}_{3} / \mathrm{MeOH}=30: 1\right)$ to yield compound 4a (yellow oil, $\left.0.64 \mathrm{~g}, 85.6 \%\right) .{ }^{1} \mathrm{H}-\mathrm{NMR}\left(300 \mathrm{MHz}, \mathrm{CDCl}_{3}\right)$ $\delta_{\mathrm{H}}(\mathrm{ppm}): 1.90-1.99(\mathrm{~m}, 2 \mathrm{H}), 2.29(\mathrm{~s}, 3 \mathrm{H}), 2.54-2.59(\mathrm{~m}, 4 \mathrm{H}), 3.02(\mathrm{~s}, 1 \mathrm{H}), 3.61(\mathrm{t}, 2 \mathrm{H}, J=5.1 \mathrm{~Hz})$, $7.75(\mathrm{dd}, 2 \mathrm{H}, J=7.5,8.1 \mathrm{~Hz}), 8.21(\mathrm{~d}, 2 \mathrm{H}, J=8.4 \mathrm{~Hz}), 8.59-8.61(\mathrm{~m}, 2 \mathrm{H}) .{ }^{13} \mathrm{C}-\mathrm{NMR}(75 \mathrm{MHz}$, $\left.\mathrm{CDCl}_{3}\right): \delta 164.2(2 \mathrm{C}), 133.9(2 \mathrm{C}), 131.5,131.2(3 \mathrm{C}), 126.9(2 \mathrm{C}), 122.6(2 \mathrm{C}), 59.0,58.5,55.2,41.4$, 38.5, 25.7; HRMS (ESI): Calcd for $\mathrm{C}_{18} \mathrm{H}_{21} \mathrm{~N}_{2} \mathrm{O}_{3}: 313.1547[\mathrm{M}+\mathrm{H}]^{+}$, Found: $313.1560[\mathrm{M}+\mathrm{H}]^{+}$.

N-[2-(1,3-Dioxo-2,3-dihydro-1H-benz[de]-isoquinolin-2-yl)propyl]-N-methyl-3-amino-1-propanol (4b). Compound $\mathbf{4 b}$ was synthesized by a similar procedure as the synthesis of $\mathbf{4 a}$. Compound $\mathbf{3 b}$ ( $852 \mathrm{mg}$, $2.72 \mathrm{mmol}$ ) was employed to produce $4 \mathbf{b}$ (yellow oil, $0.68 \mathrm{~g}, 77 \%$ ). ${ }^{1} \mathrm{H}-\mathrm{NMR}\left(300 \mathrm{MHz}, \mathrm{CDCl}_{3}\right) \delta_{\mathrm{H}}$ (ppm): 1.70-1.77 (m, 2H), 1.90-2.00 (m, 2H), $2.31(\mathrm{~s}, 3 \mathrm{H}), 2.55$ (t, 2H, $J=7.5 \mathrm{~Hz}), 2.64(\mathrm{t}, 2 \mathrm{H}, J=$ $5.7 \mathrm{~Hz}), 3.84(\mathrm{t}, 2 \mathrm{H}, J=5.4 \mathrm{~Hz}), 4.22(\mathrm{t}, 2 \mathrm{H}, J=7.5 \mathrm{~Hz}), 5.30(\mathrm{~s}, 1 \mathrm{H}, \mathrm{OH}), 7.75(\mathrm{dd}, 2 \mathrm{H}, J=8.4,7.2$ $\mathrm{Hz}), 8.21(\mathrm{~d}, 2 \mathrm{H}, J=8.4 \mathrm{~Hz}), 8.59(\mathrm{~d}, 2 \mathrm{H}, J=7.2 \mathrm{~Hz}) .{ }^{13} \mathrm{C}-\mathrm{NMR}\left(75 \mathrm{MHz}, \mathrm{CDCl}_{3}\right): \delta 164.1(2 \mathrm{C})$, 133.9 (2C), 131.5, 131.2 (3C), 126.9 (2C), 122.5 (2C), 64.3, 57.8, 55.9, 41.8, 38.5, 27.8, 25.6; HRMS (ESI): Calcd for $\mathrm{C}_{19} \mathrm{H}_{23} \mathrm{~N}_{2} \mathrm{O}_{3}: 327.1703[\mathrm{M}+\mathrm{H}]^{+}$, Found: $327.1704[\mathrm{M}+\mathrm{H}]^{+}$. 
$N$-[2-(1,3-Dioxo-2,3-dihydro-1H-benz[de]-isoquinolin-2-yl)propyl]-N-methyl-2-chloroethanamine (5a). To a solution of compound $4 \mathbf{a}(579 \mathrm{mg}, 1.86 \mathrm{mmol})$ in $\mathrm{CHCl}_{3}(30 \mathrm{~mL})$ was added $\mathrm{SOCl}_{2}(1 \mathrm{~mL})$ dropwise and the mixture was stirred at room temperature for $48 \mathrm{~h}$. Removal of the solvent under reduced pressure gave the crude product, which was dissolved in water, treated with $\mathrm{Na}_{2} \mathrm{CO}_{3}$ until $\mathrm{pH}>7$, and extracted with $\mathrm{CH}_{2} \mathrm{Cl}_{2}$. The organic layer was dried with $\mathrm{Na}_{2} \mathrm{SO}_{4}$ and purified by column chromatography $\left(\mathrm{CHCl}_{3} / \mathrm{MeOH}=50: 1\right)$ to yield compound 5a (pale yellow solid, 80.0\%). ${ }^{1} \mathrm{H}-\mathrm{NMR}$ $\left(300 \mathrm{MHz}, \mathrm{CDCl}_{3}\right) \delta_{\mathrm{H}}(\mathrm{ppm}): 1.87-1.97(\mathrm{~m}, 2 \mathrm{H}), 2.32(\mathrm{~s}, 3 \mathrm{H}), 2.59(\mathrm{t}, 2 \mathrm{H}, J=7.2 \mathrm{~Hz}), 2.74(\mathrm{t}, 2 \mathrm{H}, J=$ $7.2 \mathrm{~Hz}), 3.56$ (t, 2H, $J=7.2 \mathrm{~Hz}), 4.23(\mathrm{t}, 2 \mathrm{H}, J=7.5 \mathrm{~Hz}), 7.75(\mathrm{dd}, 2 \mathrm{H}, J=7.8,7.5 \mathrm{~Hz}), 8.21(\mathrm{~d}, 2 \mathrm{H}, J$ $=8.1 \mathrm{~Hz}), 8.59(\mathrm{~d}, 2 \mathrm{H}, J=7.2 \mathrm{~Hz}) .{ }^{13} \mathrm{C}-\mathrm{NMR}\left(75 \mathrm{MHz}, \mathrm{CDCl}_{3}\right): \delta 164.2(2 \mathrm{C}), 133.9(2 \mathrm{C}), 131.6,131.2$, 131.1 (2C), 126.9 (2C), 122.7 (2C), 58.9, 55.3, 42.1, 41.6, 38.7, 25.7; HRMS (ESI): Calcd for $\mathrm{C}_{18} \mathrm{H}_{20} \mathrm{ClN}_{2} \mathrm{O}_{2}: 331.1208[\mathrm{M}+\mathrm{H}]^{+}$, Found: $331.1219[\mathrm{M}+\mathrm{H}]^{+}$.

$\mathrm{N}$-[2-(1,3-Dioxo-2,3-dihydro-1H-benz[de]-isoquinolin-2-yl)propyl]-N-methyl-3-chloro-1-propylamine (5b). Compound 5b was synthesized by a similar procedure as the synthesis of 5a. Compound $\mathbf{4 b}$ (625 mg, $1.92 \mathrm{mmol}$ ) was employed to produce $\mathbf{5 b}$ (light yellow solid, $0.55 \mathrm{~g}, 82.9 \%) .{ }^{1} \mathrm{H}-\mathrm{NMR}$ (300 $\mathrm{MHz}, \mathrm{CDCl}_{3}$ ) $\delta_{\mathrm{H}}(\mathrm{ppm}): 2.36-2.39$ (brs, 4H), 3.78 (s, 3H), 3.16 (brs, 4H), 3.67 (t, 2H, J=5.4 Hz), 4.32 $(\mathrm{t}, 2 \mathrm{H}, J=6.9 \mathrm{~Hz}), 7.78(\mathrm{t}, 2 \mathrm{H}, J=7.8 \mathrm{~Hz}), 8.25(\mathrm{~d}, 2 \mathrm{H}, J=8.4 \mathrm{~Hz}), 8.60(\mathrm{~d}, 2 \mathrm{H}, J=7.2 \mathrm{~Hz})$. ${ }^{13} \mathrm{C}-\mathrm{NMR}\left(75 \mathrm{MHz}, \mathrm{CDCl}_{3}\right.$ ): $\delta 164.2$ (2C), 134.4 (2C), 131.6 (4C), 128.1, 127.0, 122.1 (2C), 54.3, 54.1, 41.8, 40.1, 37.6, 26.9, 22.9; HRMS (ESI): Calcd for $\mathrm{C}_{19} \mathrm{H}_{22} \mathrm{ClN}_{2} \mathrm{O}_{2}: 345.1364[\mathrm{M}+\mathrm{H}]^{+}$, Found: $345.1361[\mathrm{M}+\mathrm{H}]^{+}$.

$N$-[2-(1,3-Dioxo-2,3-dihydro-1H-benz[de]-isoquinolin-2-yl)propyl]-N-methyl-N', $N^{\prime}$-bis(2-hydroxyethyl)ethylenediamine (6a). A mixture of compound $\mathbf{5 a}(431 \mathrm{mg}, 1.31 \mathrm{mmol}), \mathrm{K}_{2} \mathrm{CO}_{3}(300 \mathrm{mg}, 2.17 \mathrm{mmol}$ ), $\mathrm{KI}(100 \mathrm{mg}, 0.60 \mathrm{mmol})$ and diethanolamine $(0.8 \mathrm{~mL})$ in $\mathrm{CH}_{3} \mathrm{CN}(15 \mathrm{~mL})$ was stirred at $80{ }^{\circ} \mathrm{C}$ under $\mathrm{N}_{2}$ for $72 \mathrm{~h}$. The resulting mixture was evaporated under reduced pressure to give the crude product. The residue was dissolved in water $(50 \mathrm{~mL})$ and extracted with $\mathrm{CH}_{2} \mathrm{Cl}_{2}$. The organic layer was dried with $\mathrm{Na}_{2} \mathrm{SO}_{4}$ and purified by column chromatography $\left(\mathrm{CHCl}_{3} / \mathrm{MeOH}=30: 1 \sim 10: 1\right)$ to yield compound 6a (yellow oil, 58\%). ${ }^{1} \mathrm{H}-\mathrm{NMR}\left(300 \mathrm{MHz}, \mathrm{CDCl}_{3}\right) \delta_{\mathrm{H}}$ (ppm): 1.93-1.98 (m, 2H), $2.28(\mathrm{~s}, 3 \mathrm{H}), 2.49-2.71$ (m, 10H), $3.58(\mathrm{~m}, 4 \mathrm{H}), 4.20$ (t, 2H, $J=7.5 \mathrm{~Hz}), 4.34$ (brs, 2H, OH), 7.70-7.75 (m, 2H), $8.18(\mathrm{~d}, 2 \mathrm{H}$, $J=8.1 \mathrm{~Hz}), 8.56(\mathrm{~d}, 2 \mathrm{H}, J=7.2 \mathrm{~Hz}) .{ }^{13} \mathrm{C}-\mathrm{NMR}\left(75 \mathrm{MHz}, \mathrm{CDCl}_{3}\right): \delta 164.0(2 \mathrm{C}), 133.8(2 \mathrm{C}), 131.4$, 131.1 (3C), 126.8 (2C), 122.4 (2C), 59.9 (2C), 57.3 (2C), 56.1, 55.1, 51.7, 41.5, 38.6, 25.0; HRMS (ESI): Calcd for $\mathrm{C}_{22} \mathrm{H}_{30} \mathrm{~N}_{3} \mathrm{O}_{4}: 400.2231[\mathrm{M}+\mathrm{H}]^{+}$, Found: $400.2241[\mathrm{M}+\mathrm{H}]^{+}$.

$N$-[2-(1,3-Dioxo-2,3-dihydro-1H-benz[de]-isoquinolin-2-yl)propyl]-N-methyl-N',N'-bis(2-hydroxyethyl)1,3-diamine (6b). Compound $\mathbf{6 b}$ was synthesized by a similar procedure as the synthesis of $6 \mathbf{a}$. Compound $\mathbf{5 b}\left(451 \mathrm{mg}, 1.31 \mathrm{mmol}\right.$ ) was employed to produce $\mathbf{6 b}$ (yellow oil, 91.2\%). ${ }^{1} \mathrm{H}-\mathrm{NMR}$ $\left(300 \mathrm{MHz}, \mathrm{CDCl}_{3}\right) \delta_{\mathrm{H}}(\mathrm{ppm}): 1.66(\mathrm{t}, 2 \mathrm{H}, J=6.3 \mathrm{~Hz}), 1.95(\mathrm{t}, 2 \mathrm{H}, J=6.9 \mathrm{~Hz}), 2.25(\mathrm{~s}, 3 \mathrm{H}), 2.47-2.65$ $(\mathrm{m}, 10 \mathrm{H}), 3.63(\mathrm{t}, 3 \mathrm{H}, J=5.1 \mathrm{~Hz}), 3.99(\mathrm{brs}, 2 \mathrm{H}), 4.21(\mathrm{t}, 2 \mathrm{H}, J=7.5 \mathrm{~Hz}), 7.74(\mathrm{t}, 2 \mathrm{H}, J=7.5 \mathrm{~Hz})$, $8.20(\mathrm{~d}, 2 \mathrm{H}, J=8.1 \mathrm{~Hz}), 8.58(\mathrm{~d}, 2 \mathrm{H}, J=7.5 \mathrm{~Hz}) .{ }^{13} \mathrm{C}-\mathrm{NMR}\left(75 \mathrm{MHz}, \mathrm{CDCl}_{3}\right): \delta 164.1(2 \mathrm{C}), 133.9$ (2C), 131.4, 131.1 (2C), 128.0, 126.9 (2C), 122.5 (2C), 59.9 (2C), 56.1 (2C), 54.9, 54.6, 52.0, 41.9, 38.8, 25.0, 24.4; HRMS (ESI): Calcd for $\mathrm{C}_{23} \mathrm{H}_{32} \mathrm{~N}_{3} \mathrm{O}_{4}: 414.2387[\mathrm{M}+\mathrm{H}]^{+}$, Found: $414.2384[\mathrm{M}+\mathrm{H}]^{+}$. 
$N$-[2-(1,3-Dioxo-2,3-dihydro-1H-benz[de]-isoquinolin-2-yl)propyl]-N-methyl-N',N'-bis(2-chloroethyl)ethylenediamine (7a). The solution of compound $\mathbf{6 a}(75 \mathrm{mg}, 0.19 \mathrm{mmol})$ in $\mathrm{SOCl}_{2}(2 \mathrm{~mL})$ was stirred at room temperature overnight. The remaining $\mathrm{SOCl}_{2}$ was completely removed by adding $\mathrm{Et}_{2} \mathrm{O}$ and then condensing the mixture several times in vacuo. The residue was dissolved in $\mathrm{CH}_{2} \mathrm{Cl}_{2}$; by adding $\mathrm{Et}_{2} \mathrm{O}$ into the solution, a white solid was formed and a gray solid was obtained by filtration with a yield of $85 \%$. The purity of $7 \mathbf{a}$ as determined by NMR meets the requirements for the cytotoxicity assay. ${ }^{1} \mathrm{H}-\mathrm{NMR}\left(300 \mathrm{MHz}, \mathrm{D}_{2} \mathrm{O}\right) \delta_{\mathrm{H}}(\mathrm{ppm}): 1.93$ (brs, 2H), 2.88 (s, 3H), 3.46-3.86 (m, 14H), 7.24-7.30 (m, 2H), 7.72-7.78 (m, 4H). ${ }^{13} \mathrm{C}-\mathrm{NMR}\left(75 \mathrm{MHz}, \mathrm{D}_{2} \mathrm{O}\right): \delta 165.2$ (2C), $135.8(2 \mathrm{C}), 131.9,130.9$ (3C), 127.5 (2C), 120.3 (2C), 55.6(4C), 51.5, 48.4, 40.7, 39.1, 37.6, 24.9.HRMS (ESI): Calcd for $\mathrm{C}_{22} \mathrm{H}_{28} \mathrm{Cl}_{2} \mathrm{~N}_{3} \mathrm{O}_{2}$ : $436.1553[\mathrm{M}+\mathrm{H}]^{+}$, Found: $436.1559[\mathrm{M}+\mathrm{H}]^{+}$.

$N$-[2-(1,3-Dioxo-2,3-dihydro-1H-benz[de]-isoquinolin-2-yl)propyl]-N-methyl-N',N'-bis(2-chloroethyl)1,3-diamine (7b). To a solution of compound $\mathbf{6 b}(123 \mathrm{mg}, 0.30 \mathrm{mmol})$ in $\mathrm{CHCl}_{3}(20 \mathrm{~mL})$ was added $\mathrm{SOCl}_{2}(0.15 \mathrm{~mL})$ dropwise, and the solution became turbid. After the reaction was kept at $65^{\circ} \mathrm{C}$ for $4 \mathrm{~h}$, the solution became clear. The solvent was removed in vacuo to give the crude product, which was dissolved in conc. $\mathrm{NaHCO}_{3}$ solution and extracted with $\mathrm{CH}_{2} \mathrm{Cl}_{2}$. The organic layer was washed by conc. $\mathrm{NaCl}$, dried by $\mathrm{Na}_{2} \mathrm{SO}_{4}$ and purified by column chromatography $\left(\mathrm{CHCl}_{3} / \mathrm{MeOH}=50: 1\right)$ to yield $7 \mathbf{b}$ (yellow oil, 45\%) ${ }^{1} \mathrm{H}-\mathrm{NMR}\left(300 \mathrm{MHz}, \mathrm{CDCl}_{3}\right) \delta_{\mathrm{H}}(\mathrm{ppm}): 1.62$ (t, 2H, $\left.J=7.2 \mathrm{~Hz}\right), 1.92-1.99$ (m, 2H), $2.27(\mathrm{~s}, 3 \mathrm{H}), 2.43(\mathrm{t}, 2 \mathrm{H}, J=6.6 \mathrm{~Hz}), 2.52-2.62(\mathrm{~m}, 4 \mathrm{H}), 2.84$ (t, $4 \mathrm{H}, J=7.2 \mathrm{~Hz}), 3.50$ (t, 4H, J=6.9 Hz), $4.22(\mathrm{t}, 2 \mathrm{H}, J=7.5 \mathrm{~Hz}), 7.74(\mathrm{t}, 2 \mathrm{H}, J=7.8 \mathrm{~Hz}), 8.19(\mathrm{~d}, 2 \mathrm{H}, J=7.8 \mathrm{~Hz}), 8.57(\mathrm{~d}, 2 \mathrm{H}, J=7.2 \mathrm{~Hz})$. ${ }^{13} \mathrm{C}-\mathrm{NMR}\left(75 \mathrm{MHz}, \mathrm{CDCl}_{3}\right.$ ): $\delta 164.0(2 \mathrm{C}), 133.8(2 \mathrm{C}), 131.4,131.1(3 \mathrm{C}), 127.9,126.8,122.5(2 \mathrm{C})$, 56.3 (2C), 55.2, 54.9, 52.4, 41.9 (2C), 41.7, 38.7, 25.4, 25.2; HRMS (ESI): Calcd for $\mathrm{C}_{23} \mathrm{H}_{30} \mathrm{Cl}_{2} \mathrm{~N}_{3} \mathrm{O}_{2}$ : $450.1710[\mathrm{M}+\mathrm{H}]^{+}$, Found:450.1716 [M+H] $]^{+}$.

N,N-Bis[2-(1,3-dioxo-2,3-dihydro-1H-benz[de]-isoquinolin-2-yl)propyl]ethanolamine (8a). A mixture of compound 2 (318 mg, $1 \mathrm{mmol}$ ), ethanolamine ( $30 \mu \mathrm{L}, 0.5 \mathrm{mmol})$ and $\mathrm{K}_{2} \mathrm{CO}_{3}(552 \mathrm{mg}, 4 \mathrm{mmol})$ in $\mathrm{CH}_{3} \mathrm{CN}(10 \mathrm{~mL})$ was heated at $80{ }^{\circ} \mathrm{C}$ in and oil bath under $\mathrm{N}_{2}$ for $24 \mathrm{~h}$. The resulting mixture was filtrated to remove the solid salt and concentrated in vacuo, then purified by column chromatography over silica gel $\left(\mathrm{CH}_{2} \mathrm{Cl}_{2} / \mathrm{MeOH}=30: 1 \sim 20: 1\right)$ to yield 8a (light yellow solid, $\left.174 \mathrm{mg}, 65 \%\right)$. ${ }^{1} \mathrm{H}-\mathrm{NMR}$ (300 MHz, $\left.\mathrm{CDCl}_{3}\right) \delta_{\mathrm{H}}(\mathrm{ppm}): 1.87-1.96(\mathrm{~m}, 4 \mathrm{H}), 2.64-2.69(\mathrm{~m}, 6 \mathrm{H}), 3.63(\mathrm{~m}, 2 \mathrm{H}), 4.24(\mathrm{t}, 4 \mathrm{H}, J=7.5 \mathrm{~Hz})$, $7.71(\mathrm{t}, 4 \mathrm{H}, J=7.5 \mathrm{~Hz}), 8.16(\mathrm{~d}, 4 \mathrm{H}, J=8.1 \mathrm{~Hz}), 8.54(\mathrm{~d}, 4 \mathrm{H}, J=7.2 \mathrm{~Hz}) .{ }^{13} \mathrm{C}-\mathrm{NMR}(75 \mathrm{MHz}$, $\mathrm{CDCl}_{3}$ ): $\delta 164.0(4 \mathrm{C}), 133.8(4 \mathrm{C}), 131.4(2 \mathrm{C}), 131.1$ (4C), $128.0(2 \mathrm{C}), 126.8(4 \mathrm{C}), 122.6(4 \mathrm{C}), 59.1$, 56.3, $51.6(2 \mathrm{C}), 38.6(2 \mathrm{C}), 25.7(2 \mathrm{C})$; HRMS (ESI): Calcd for $\mathrm{C}_{32} \mathrm{H}_{30} \mathrm{~N}_{3} \mathrm{O}_{5}: 536.2180[\mathrm{M}+\mathrm{H}]^{+}$, Found:536.2184 [M+H] $]^{+}$.

N,N-Bis[2-(1,3-dioxo-2,3-dihydro-1H-benz[de]-isoquinolin-2-yl)propyl]-3-amino-1-propanol

$(8 \mathbf{b})$.

Compound $\mathbf{8 b}$ was synthesized by a similar procedure as the synthesis of $\mathbf{8 a}$. Compound $\mathbf{2}$ (318 $\mathrm{mg}$, $1 \mathrm{mmol})$, 3-amino-1-propanol $(0.037 \mathrm{~mL}, 0.5 \mathrm{mmol})$ and $\mathrm{K}_{2} \mathrm{CO}_{3}(552 \mathrm{mg}, 4 \mathrm{mmol})$ were employed to produce 8b (light yellow oil, $137 \mathrm{mg}, 50 \%) .{ }^{1} \mathrm{H}-\mathrm{NMR}\left(300 \mathrm{MHz}, \mathrm{CDCl}_{3}\right) \delta_{\mathrm{H}}(\mathrm{ppm}): 1.76(\mathrm{~m}, 2 \mathrm{H})$, $1.95(\mathrm{~m}, 4 \mathrm{H}), 2.64-2.72(\mathrm{~m}, 6 \mathrm{H}), 3.88(\mathrm{t}, 2 \mathrm{H}), 4.21(\mathrm{t}, 4 \mathrm{H}, J=7.5 \mathrm{~Hz}), 7.69(\mathrm{t}, 4 \mathrm{H}, J=7.2 \mathrm{~Hz})$, $8.15(\mathrm{~d}, 4 \mathrm{H}, J=8.4 \mathrm{~Hz}), 8.49(\mathrm{~d}, 4 \mathrm{H}, J=7.5 \mathrm{~Hz}) .{ }^{13} \mathrm{C}-\mathrm{NMR}\left(75 \mathrm{MHz}, \mathrm{CDCl}_{3}\right): \delta 163.9(4 \mathrm{C}), 133.7$ (4C), 
131.3 (2C), 130.9 (4C), 127.8 (2C), 126.7 (4C), 122.3 (4C), 62.9, 52.7, 51.6 (2C), 38.7 (2C), 28.4, 25.2 (2C); HRMS (ESI): Calcd for $\mathrm{C}_{33} \mathrm{H}_{32} \mathrm{~N}_{3} \mathrm{O}_{5}: 550.2336[\mathrm{M}+\mathrm{H}]^{+}$, Found: $550.2346[\mathrm{M}+\mathrm{H}]^{+}$.

N,N-Bis[2-(1,3-dioxo-2,3-dihydro-1H-benz[de]-isoquinolin-2-yl)propyl]-3-chloro-1-propylamine (9b). To a solution of compound $\mathbf{8 b}(1.100 \mathrm{~g}, 2.0 \mathrm{mmol})$ in $\mathrm{CHCl}_{3}(20 \mathrm{~mL})$ was added $\mathrm{SOCl}_{2}(0.8 \mathrm{~mL})$ dropwise and the mixture was stirred at room temperature for 2 days. The resulting mixture was concentrated under reduced pressure to give a yellow solid residue. The residue was rapidly purified by column chromatography over silica gel $\left(\mathrm{CH}_{2} \mathrm{Cl}_{2} / \mathrm{MeOH}=40: 1\right)$ to yield $\mathbf{9 b}$ (light yellow solid, $87.5 \%$ ). Compound 9b was easily transferred into the corresponding ammonium salt, so it should be used immediately for next step. ${ }^{1} \mathrm{H}-\mathrm{NMR}\left(300 \mathrm{MHz}, \mathrm{CDCl}_{3}\right) \delta_{\mathrm{H}}(\mathrm{ppm}): 1.88-2.04(\mathrm{~m}, 6 \mathrm{H}), 2.64(\mathrm{t}, 6 \mathrm{H}$, $J=6.3 \mathrm{~Hz}), 3.69(\mathrm{t}, 2 \mathrm{H}, J=6.3 \mathrm{~Hz}), 4.21(\mathrm{t}, 4 \mathrm{H}, J=6.6 \mathrm{~Hz}), 7.68(\mathrm{t}, 4 \mathrm{H}, J=7.2 \mathrm{~Hz}), 8.26(\mathrm{~d}, 4 \mathrm{H}$, $J=8.1 \mathrm{~Hz}), 8.77(\mathrm{~d}, 4 \mathrm{H}, J=7.2 \mathrm{~Hz}) .{ }^{13} \mathrm{C}-\mathrm{NMR}\left(75 \mathrm{MHz} \mathrm{CDCl}_{3}\right): \delta 163.8(4 \mathrm{C}), 133.6(4 \mathrm{C}), 131.3(2 \mathrm{C})$, 130.9 (4C), 127.8 (2C), 126.7 (4C), 122.5 (4C), 51.6, 50.7 (2C), 43.4, 38.8 (2C), 30.5, 25.5 (2C); HRMS (ESI): Calcd for $\mathrm{C}_{33} \mathrm{H}_{30} \mathrm{ClN}_{3} \mathrm{O}_{4}: 568.2003[\mathrm{M}+\mathrm{H}]^{+}$, Found: $568.1982[\mathrm{M}+\mathrm{H}]^{+}$.

$N, N$-Bis [2-(1,3-dioxo-2,3-dihydro-1H-benz[de]-isoquinolin-2-yl)propyl]-N',N'-bis(2-hydroxyethyl)ethylenediamine (10a). The synthesis of compound 10a was divided into two parts. Firstly, compound 8a (560 mg, $1.05 \mathrm{mmol}$ ) was employed to produce 9a through a similar procedure as 9b. Then compound 9a was directly used for the next step. A mixture of $9 \mathbf{a}(350 \mathrm{mg}, 0.63 \mathrm{mmol}), \mathrm{K}_{2} \mathrm{CO}_{3}(540 \mathrm{mg}$, $3.91 \mathrm{mmol})$, $\mathrm{KI}(100 \mathrm{mg}, 0.60 \mathrm{mmol})$ and diethanolamine $(0.8 \mathrm{~mL})$ in $\mathrm{CH}_{3} \mathrm{CN}(10 \mathrm{~mL})$ was refluxed under $\mathrm{N}_{2}$ for $60 \mathrm{~h}$. The resulting mixture was filtrated to remove solid $\mathrm{K}_{2} \mathrm{CO}_{3}$, and then concentrated under reduced pressure. The crude product was purified by column chromatography over silica gel $\left(\mathrm{CHCl}_{3} / \mathrm{MeOH}=30: 1\right)$ to yield 10a (light yellow oil, 86.0\%). ${ }^{1} \mathrm{H}-\mathrm{NMR}\left(300 \mathrm{MHz}, \mathrm{CDCl}_{3}\right) \delta_{\mathrm{H}}(\mathrm{ppm})$ : $1.94(\mathrm{t}, 4 \mathrm{H}, J=6.9 \mathrm{~Hz}), 2.62-2.70(\mathrm{~m}, 12 \mathrm{H}), 3.61(\mathrm{brs}, 6 \mathrm{H}), 4.22(\mathrm{t}, 4 \mathrm{H}, J=6.6 \mathrm{~Hz}), 7.72(\mathrm{t}, 4 \mathrm{H}$, $J=7.2 \mathrm{~Hz}), 8.18(\mathrm{~d}, 4 \mathrm{H}, J=8.1 \mathrm{~Hz}), 8.54(\mathrm{~d}, 4 \mathrm{H}, J=7.2 \mathrm{~Hz}) \cdot{ }^{13} \mathrm{C}-\mathrm{NMR}\left(75 \mathrm{MHz}, \mathrm{CDCl}_{3}\right): \delta 164.1$ (4C), 133.8 (4C), 131.4 (2C), 131.1 (6C), 126.8 (4C), 122.6 (4C), 59.9 (2C), 57.2 (2C), 52.6, 52.4, 51.4 (2C), 38.9 (2C), 24.8 (2C); HRMS (ESI): Calcd for $\mathrm{C}_{36} \mathrm{H}_{39} \mathrm{~N}_{4} \mathrm{O}_{6}: 536.2180[\mathrm{M}+\mathrm{H}]^{+}$, Found:536.2848 $[\mathrm{M}+\mathrm{H}]^{+}$.

$N, N$-Bis[2-(1,3-dioxo-2,3-dihydro-1H-benz[de]-isoquinolin-2-yl)propyl]-N',N'-bis(2-hydroxyethyl)-1,3diamine (10b). Compound 10b was synthesized by a similar procedure as the synthesis of 10a. Compound $\mathbf{8 b}$ (1.000 g, $1.8 \mathrm{mmol}$ ) was employed to produce $\mathbf{9 b}$, which was then used immediately for the next step to yield 10b (light yellow oil, 81.6\%). ${ }^{1} \mathrm{H}-\mathrm{NMR}\left(300 \mathrm{MHz}, \mathrm{CDCl}_{3}\right) \delta_{\mathrm{H}}$ (ppm): $1.68-1.73$ $(\mathrm{t}, 2 \mathrm{H}), 1.89-1.96(\mathrm{~m}, 4 \mathrm{H}), 2.56-2.68(\mathrm{~m}, 12 \mathrm{H}), 3.38$ (brs, 2H), 3.64-3.67 (t, 4H), 4.22 (t, 4H, J= 7.5 Hz), $7.72(\mathrm{t}, 4 \mathrm{H}, J=7.5 \mathrm{~Hz}), 8.17(\mathrm{~d}, 4 \mathrm{H}, J=7.8 \mathrm{~Hz}), 8.55(\mathrm{~d}, 4 \mathrm{H}, J=7.5 \mathrm{~Hz}) .{ }^{13} \mathrm{C}-\mathrm{NMR}(75 \mathrm{MHz}$, $\mathrm{CDCl}_{3}$ ): $\delta 164.2(4 \mathrm{C}), 133.8$ (4C), 131.5 (2C), $131.2(4 \mathrm{C}), 128.0$ (2C), 126.9 (4C), 122.6 (4C), $59.8(2 \mathrm{C})$, 56.6 (2C), 52.8, 51.8 (2C), 51.1, 39.0 (2C), 25.3 (2C), 24.8; HRMS (ESI): Calcd for $\mathrm{C}_{37} \mathrm{H}_{41} \mathrm{~N}_{4} \mathrm{O}_{6}$ : $637.3021[\mathrm{M}+\mathrm{H}]^{+}$, Found: $637.3027[\mathrm{M}+\mathrm{H}]^{+}$.

$N, N$-Bis[2-(1,3-dioxo-2,3-dihydro-1H-benz[de]-isoquinolin-2-yl)propyl]- $N^{\prime}, N^{\prime}$-bis(2-chloroethyl)ethylenediamine hydrochloride (11a). The solution of compound $10 \mathrm{a}(50 \mathrm{mg}, 0.08 \mathrm{mmol})$ in $\mathrm{SOCl}_{2}(1 \mathrm{~mL})$ was stirred at room temperature overnight. The remaining $\mathrm{SOCl}_{2}$ was completely removed by adding $\mathrm{Et}_{2} \mathrm{O}$ and then condensed for several times in vacuo. The residue was dissolved in a mixed solution of 
methanol and a little methylene chloride, then a drop of concentrated hydrochloric acid was added to afford a white solid precipitate. The suspension was filtered to yield crude product 11a hydrochloride as white solid (30 mg, 51.0\%). ${ }^{1} \mathrm{H}-\mathrm{NMR}$ (300 MHz, DMSO- $\left.d_{6}\right) \delta_{\mathrm{H}}(\mathrm{ppm}): 2.09$ (brs, 4H), 3.07-3.77 (brs, 16H), 4.09 (t, 4H, $J=6.3 \mathrm{~Hz}), 7.82$ (t, 4H, $J=7.8 \mathrm{~Hz}), 8.36-8.44(\mathrm{~m}, 8 \mathrm{H}) .{ }^{13} \mathrm{C}-\mathrm{NMR}(75 \mathrm{MHz}$, DMSO- $d_{6}$ ): $\delta 163.7$ (4C), 134.5 (4C), 131.3 (2C), 130.8 (4C), 127.4 (2C), 127.2 (4C), 122.1 (4C), 54.4 (2C), 50.3 (2C), 47.6 (2C), 37.2 (4C), 22.1 (2C); HRMS (ESI): Calcd for $\mathrm{C}_{36} \mathrm{H}_{37} \mathrm{Cl}_{2} \mathrm{~N}_{4} \mathrm{O}_{4}: 659.2186$ $[\mathrm{M}+\mathrm{H}]^{+}$, Found:659.2180 $[\mathrm{M}+\mathrm{H}]^{+}$.

N,N-Bis[2-(1,3-dioxo-2,3-dihydro-1H-benz[de]-isoquinolin-2-yl)propyl]-N',N'-bis(2-chloroethyl)-1,3diamine (11b). To a solution of compound $\mathbf{1 0 b}(190 \mathrm{mg}, 0.30 \mathrm{mmol})$ in $\mathrm{CHCl}_{3}(25 \mathrm{~mL})$ was added $\mathrm{SOCl}_{2}(0.15 \mathrm{~mL})$ dropwise and the mixture stirred at $65{ }^{\circ} \mathrm{C}$ for $2 \mathrm{~h}$. The solvent was removed under reduced pressure, then water $(20 \mathrm{~mL})$ and solid $\mathrm{Na}_{2} \mathrm{CO}_{3}$ were added to neutralize the solution, which was extracted with $\mathrm{CH}_{2} \mathrm{Cl}_{2}(50 \mathrm{~mL})$. The organic layer was washed with saturated $\mathrm{NaCl}$, dried over $\mathrm{MgSO}_{4}$, concentrated and then purified by column chromatography over silica gel $\left(\mathrm{CHCl}_{3} / \mathrm{MeOH}=50: 1\right)$ to yield 11b (yellow oil, 77.0\%). ${ }^{1} \mathrm{H}-\mathrm{NMR}\left(300 \mathrm{MHz}, \mathrm{CDCl}_{3}\right) \delta_{\mathrm{H}}$ (ppm): 1.65 (brs, 2H), 1.92 (brs, 4H), 2.63-2.67 (m, 8H), $2.86(\mathrm{t}, 4 \mathrm{H}, J=7.2 \mathrm{~Hz}), 3.51(\mathrm{t}, 4 \mathrm{H}, J=7.2 \mathrm{~Hz}), 4.23(\mathrm{t}, 4 \mathrm{H}, J=7.2 \mathrm{~Hz}), 7.72$ (t, $4 \mathrm{H}, J=7.8 \mathrm{~Hz}), 8.18(\mathrm{~d}, 4 \mathrm{H}, J=7.8 \mathrm{~Hz}), 8.54(\mathrm{~d}, 4 \mathrm{H}, J=7.2 \mathrm{~Hz}) \cdot{ }^{13} \mathrm{C}-\mathrm{NMR}\left(75 \mathrm{MHz}, \mathrm{CDCl}_{3}\right): \delta 164.0$ (4C), 133.7 (4C), 131.5 (2C), 131.1 (4C), 128.0 (2C), 126.8 (4C), 122.6 (4C), 56.4 (2C), 52.7, 51.6 (2C), 51.3, $42.0(2 \mathrm{C}), 38.8(2 \mathrm{C}), 25.2$ (3C); HRMS (ESI): Calcd for $\mathrm{C}_{37} \mathrm{H}_{39} \mathrm{Cl}_{2} \mathrm{~N}_{4} \mathrm{O}_{4}$ : 673.2343 $[\mathrm{M}+\mathrm{H}]^{+}$, Found: $673.2341[\mathrm{M}+\mathrm{H}]^{+}$.

\subsection{Fluorescence Study Experiment}

Each compound was divided into two groups: one was added with a constant concentration of ctDNA (calf thymus DNA, $50 \mu \mathrm{M}$ ) and the other was without the ctDNA as control. Various concentrations of compounds ranging from $1 \mu \mathrm{M}$ to $25 \mu \mathrm{M}(1,5,10,20$ and $25 \mu \mathrm{M})$ were used. To every sample was added Tris-HCl buffer $(25 \mathrm{mM}, \mathrm{pH}=7.4)$ to get a final volume of $4 \mathrm{~mL}$, which was stirred constantly at $30^{\circ} \mathrm{C}$ in the dark for 3 days before recording each spectrum.

\subsection{Agarosegel Cross-Linking Assay}

Each compound was tested at four concentrations $(1,5,10,50 \mu \mathrm{M})$. To each sample was added $2 \mu \mathrm{L}$ plasmid DNA (PUC-19, $0.16 \mu \mathrm{g} / \mu \mathrm{L}$ ) and various concentrations of compounds, diluted by Tris-HCl buffer $(0.05 \mathrm{M}, \mathrm{pH}=7.4)$ to reach a final volume of $15 \mu \mathrm{L}$. Every group has a pure DNA sample as blank control and its own control sample by using its own precursor in concentration of $10 \mu \mathrm{M}$. All the above samples were incubated at $37^{\circ} \mathrm{C}$ for $1 \mathrm{~h}$ and separated on an agarose gel (120 V, $\left.45 \mathrm{~min}\right)$.

\subsection{In Vitro Cytotoxicity Evaluation}

All the compounds were tested in their mono- or dihydrochloride form. The samples were prepared by adding a stoichiometric amount of $1 \mathrm{M} \mathrm{HCl}$ to the solution, and then removing the solvent to obtain the target compounds. All cells used in the research were prepared at $3.5 \times 10^{4}$ cells $/ \mathrm{mL}$ concentration and each $100 \mu \mathrm{L}$ cells suspension was seeded in 96-well cell incubated for $24 \mathrm{~h}\left(37^{\circ} \mathrm{C}, 5 \% \mathrm{CO}_{2}\right)$. Then each solution was added and incubated for another $72 \mathrm{~h}$. For the control group, equivalent 
concentration of DMSO (final concentration 0.5\%) was added. MTT (3-[4,5-dimethylthiazol-2yl]diphenyltetrazolium bromide) method was employed to measure the number of surviving cells and the $\mathrm{OD}$ value was recorded at $492 \mathrm{~nm} / 620 \mathrm{~nm}$. The $\mathrm{IC}_{50}$ values were calculated using Prism Graphpad software of the triplicate experiment.

\subsection{Flow Cytometry Assay}

Cells were trypsinized and washed twice with PBS, then fixed in $75 \%$ alcohol for at least 30 min at $4{ }^{\circ} \mathrm{C}$. The fixed cells were recovered by centrifugation and washed twice with PBS, and then stained with PI in PBS containing RNAase and $0.1 \%$ Triton-X100 for 30 min at $37{ }^{\circ} \mathrm{C}$. The cellular DNA content was measured by a FACScalibur flow cytometer (BD Bioscience, San Jose, CA, USA).

\subsection{Immunoblotting Assay}

Cells were lysed using RIPA lysis buffer containing PMSF and phosphatase/protease inhibitors. The total cellular protein extracts was qualified by BCA assay. $20 \mu \mathrm{g}$ of total protein was resolved on $10 \%$ SDS-PAGE, then electro-transferred onto PVDF membranes, and incubated with appropriate antibodies overnight at $4{ }^{\circ} \mathrm{C}$, then washed in PBS containing $0.1 \%$ Tween 20 and incubated with corresponding secondary antibodies for $1 \mathrm{~h}$ at room temperature. After that the membranes were developed with the enhanced chemiluminescence Western Blotting detection reagent (Amersham-Pharmacia, Piscataway, NJ, USA).

\section{Conclusions}

A series of mono- and bisnaphthalimide $N$-mustard derivatives were synthesized as potent antitumor agents. Through conjugating $N$-mustard to naphthalimide, improved cytotoxicity was obtained. Compound 11b exhibited considerably cytotoxicity compared with amonafide, and showed potency as an antitumor agent. Even though more investigation is still needed to evaluate the efficiency of the $\mathrm{N}$-mustard moiety, the bioactivity results suggest that the length of the flexible amine link and naphthalimide core could improve the cytotoxicity. Our work is meaningful in compensating for the lack of research in this field of combining $N$-mustards with naphthalimides.

\section{Supplementary Materials}

Supplementary materials can be accessed at: http://www.mdpi.com/1420-3049/19/7/8803/s1.

\section{Acknowledgments}

The authors thank financial supports from National Natural Science Foundation of China (NSFC No. 81273370) and the PKU Care Pharmaceutical R\&D Center. 


\section{Author Contributions}

X.M. and Z.L. conceived the project. Q.L., W.Z. and S.L. designed the experiments and executed the chemical synthesis. L.J. and S.Y. performed the biological experiments. Q.L., W.Z. and X.M. wrote the paper. All authors discussed the results and commented on the manuscript.

\section{Conflicts of Interest}

The author declares no conflict of interest.

\section{References}

1. Neidle, S.; Thurston, D.E. Chemical approaches to the discovery and development of cancer therapies. Nat. Rev. Cancer 2005, 5, 285-296.

2. Chu, P.M.; Chen, L.H.; Chen, M.T.; Ma, H.I.; Su, T.L.; Hsieh, P.C.; Chien, C.S.; Jiang, B.H.; Chen, Y.C.; Lin, Y.H.; et al. Targeting autophagy enhances BO-1051-induced apoptosis in human malignant glioma cells. Cancer Chemother. Pharmacol. 2012, 69, 621-633.

3. Kakadiya, R.; Dong, H.; Kumar, A.; Narsinh, D.; Zhang, X.; Chou, T.C.; Lee, T.C.; Shah, A.; $\mathrm{Su}$, T.L. Potent DNA-directed alkylating agents: Synthesis and biological activity of phenyl $\mathrm{N}$-mustard-quinoline conjugates having a urea or hydrazinecarboxamide linker. Bioorg. Med. Chem. 2010, 18, 2285-2299.

4. Jiang, Y.; Han, J.; Yu, C.; Vass, S.O.; Searle, P.F.; Browne, P.; Knox, R.J.; Hu, L. Design, synthesis, and biological evaluation of cyclic and acyclic nitrobenzylphosphoramide mustards for E. coli nitroreductase activation. J. Med. Chem. 2006, 49, 4333-4343.

5. Duan, J.X.; Jiao, H.L.; Kaizerman, J.; Stanton, T.; Evans, J.W.; Lan, L.; Lorente, G.; Banica, M.; Jung, D.; Wang, J.W.; et al. Potent and highly selective hypoxia-activated achiral phosphoramidate mustards as anticancer drugs. J. Med. Chem. 2008, 51, 2412-2420.

6. Kapuriya, N.; Kapuriya, K.; Dong, H.; Zhang, X.; Chou, T.C.; Chen, Y.T.; Lee, T.C.; Lee, W.C.; Tsai, T.H.; Naliapara, Y.; et al. Novel DNA-directed alkylating agents: Design, synthesis and potent antitumor effect of phenyl $N$-mustard-9-anilinoacridine conjugates via a carbamate or carbonate linker. Bioorg. Med. Chem. 2009, 17, 1264-1275.

7. Maze, R.; Carney, J.P.; Kelley, M.R.; Glassner, B.J.; Williams, D.A.; Samson, L. Increasing DNA repair methyltransferase levels via bone marrow stem cell transduction rescues mice from the toxic effects of 1,3-bis(2-chloroethyl)-1-nitrosourea, a chemotherapeutic alkylating agent. Proc. Natl. Acad. Sci. USA 1996, 93, 206-210.

8. Suzukake, K.; Vistica, B.P.; Vistica, D.T. Dechlorination of 1-phenylalanine mustard by sensitive and resistant tumor cells and its relationship to intracellular glutathione content. Biochem. Pharmacol. 1983, 32, 165-167.

9. Su, T.L.; Lin, Y.W.; Chou, T.C.; Zhang, X.; Bacherikov, V.A.; Chen, C.H.; Liu, L.F.; Tsai, T.J. Potent antitumor 9-anilinoacridines and acridines bearing an alkylating $N$-mustard residue on the acridine chromophore: Synthesis and biological activity. J. Med. Chem. 2006, 49, 3710-3718. 
10. Kapuriya, N.; Kapuriya, K.; Zhang, X.; Chou, T.C.; Kakadiya, R.; Wu, Y.T.; Tsai, T.H.; Chen, Y.T.; Lee, T.C.; Shah, A.; et al. Synthesis and biological activity of stable and potent antitumor agents, aniline nitrogen mustards linked to 9-anilinoacridines via a urea linkage. Bioorg. Med. Chem. 2008, 16, 5413-5423.

11. Kohler, B.; Su, T.L.; Chou, T.C.; Jiang, X.J.; Watanabe, K.A. Synthesis of cyclopentanthraquinones: Analogs of mitomycin C. J. Org. Chem. 1993, 58, 1680-1686.

12. Baraldi, P.G.; Beria, I.; Cozzi, P.; Geroni, C.; Espinosa, A.; Gallo, M.A.; Entrena, A.; Bingham, J.P.; Hartley, J.A.; Romagnoli, R. Cinnamoyl nitrogen mustard derivatives of pyrazole analogues of tallimustine modified at the amidino moiety: Design, synthesis, molecular modeling and antitumor activity studies. Bioorg. Med. Chem. 2004, 12, 3911-3921.

13. Baraldi, P.G.; Romagnoli, R.; Giovanna Pavani, M.; del Carmen Nunez, M.; Bingham, J.P.; Hartley, J.A. Benzoyl and cinnamoyl nitrogen mustard derivatives of benzoheterocyclic analogues of the tallimustine: Synthesis and antitumour activity. Bioorg. Med. Chem. 2002, 10, 1611-1618.

14. Baraldi, P.G.; Romagnoli, R.; Guadix, A.E.; Pineda de las Infantas, M.J.; Gallo, M.A.; Espinosa, A.; Martinez, A.; Bingham, J.P.; Hartley, J.A. Design, synthesis, and biological activity of hybrid compounds between uramustine and DNA minor groove binder distamycin A .J. Med. Chem. 2002, 45, 3630-3638.

15. Pors, K.; Paniwnyk, Z.; Ruparelia, K.C.; Teesdale-Spittle, P.H.; Hartley, J.A.; Kelland, L.R.; Patterson, L.H. Synthesis and biological evaluation of novel chloroethylaminoanthraquinones with potent cytotoxic activity against cisplatin-resistant tumor cells. J. Med. Chem. 2004, 47, 1856-1859.

16. Denny, W.A. DNA minor groove alkylating agents. Curr. Med. Chem. 2001, 8, 533-544.

17. Brana, M.F.; Ramos, A. Naphthalimides as anti-cancer agents: Synthesis and biological activity. Curr. Med. Chem. Anticancer Agents 2001, 1, 237-255.

18. Brana, M.F.; Castellano, J.M.; Moran, M.; Perez de Vega, M.J.; Perron, D.; Conlon, D.; Bousquet, P.F.; Romerdahl, C.A.; Robinson, S.P. Bis-naphthalimides 3: Synthesis and antitumor activity of N,N'-bis[2-(1,8-naphthalimido)-ethyl] alkanediamines. Anticancer Drug Des. 1996, 11, 297-309.

19. Brana, M.F.; Castellano, J.M.; Moran, M.; Perez de Vega, M.J.; Romerdahl, C.R.; Qian, X.D.; Bousquet, P.; Emling, F.; Schlick, E.; Keilhauer, G. Bis-naphthalimides: A new class of antitumor agents. Anticancer Drug Des. 1993, 8, 257-268.

20. Pain, A.; Samanta, S.; Dutta, S.; Saxena, A.K.; Shanmugavel, M.; Kampasi, H.; Qazi, G.N.; Sanyal, U. Evaluation of naphthalmustine, a nitrogen mustard derivative of naphthalimide as a rationally-designed anticancer agent. J. Exp. Clin. Cancer Res. 2003, 22, 411-418.

21. Pain, A.; Samanta, S.; Dutta, S.; Saxena, A.K.; Shanmugavel, M.; Kampasi, H.; Qazi, G.N.; Sanyal, U. Evaluation of napromustine, a nitrogen mustard derivative of naphthalimide, as a rationally designed mixed-function anticancer agent. Exp. Oncol. 2002, 24, 173-179.

22. Pain, A.; Samanta, S.; Dutta, S.; Saxena, A.K.; Shanmugavel, M.; Kampasi, H.; Quazi, G.N.; Sanyal, U. Synthesis and evaluation of substituted naphthalimide nitrogen mustards as rationally designed anticancer compounds. Acta. Pol. Pharm. 2003, 60, 285-291.

23. Xu, F.; Gan, Y.; Zhang, Y.; Luo, W.; Ma, H.; Wang, C.; Zhao, J. Synthesis and biological activity of two kinds of nitrogen mustard derivatives. Chin. J. Org. Chem. 2011, 31, 1122-1126. 
24. Hossain, S.U.; Sengupta, S.; Bhattacharya, S. Synthesis and evaluation of antioxidative properties of a series of organoselenium compounds. Bioorg. Med. Chem. 2005, 13, 5750-5758.

25. Teiichi, M.; Kiyotaka, F. One-pot synthesis of aryl sulfones from alcohols. Synthesis 2002, 4, 479-482.

26. Woo, L.W.; Bubert, C.; Sutcliffe, O.B.; Smith, A.; Chander, S.K.; Mahon, M.F.; Purohit, A.; Reed, M.J.; Potter, B.V. Dual aromatase-steroid sulfatase inhibitors. J. Med. Chem. 2007, 50, 3540-3560.

27. Hegde, R.; Thimmaiah, P.; Yerigeri, M.C.; Krishnegowda, G.; Thimmaiah, K.N.; Houghton, P.J. Anti-calmodulin acridone derivatives modulate vinblastine resistance in multidrug resistant (MDR) cancer cells. Eur. J. Med. Chem. 2004, 39, 161-177.

28. Kaufmann, S.H.; Desnoyers, S.; Ottaviano, Y.; Davidson, N.E.; Poirier, G.G. Specific proteolytic cleavage of poly(ADP-ribose) polymerase: An early marker of chemotherapy-induced apoptosis. Cancer Res. 1993, 53, 3976-3985.

Sample Availability: Samples of the compounds are available from the authors.

(C) 2014 by the authors; licensee MDPI, Basel, Switzerland. This article is an open access article distributed under the terms and conditions of the Creative Commons Attribution license (http://creativecommons.org/licenses/by/3.0/). 